
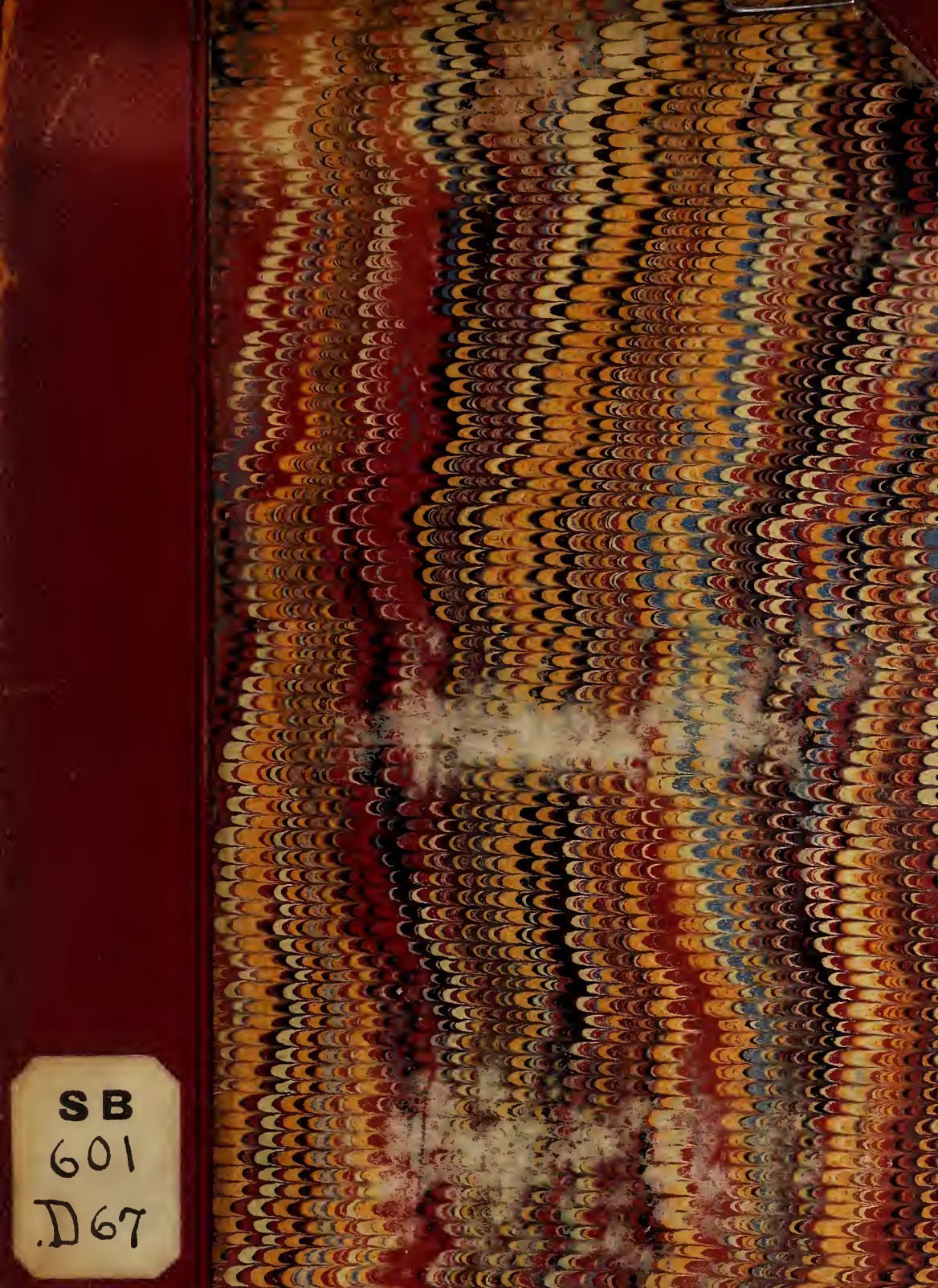

arec

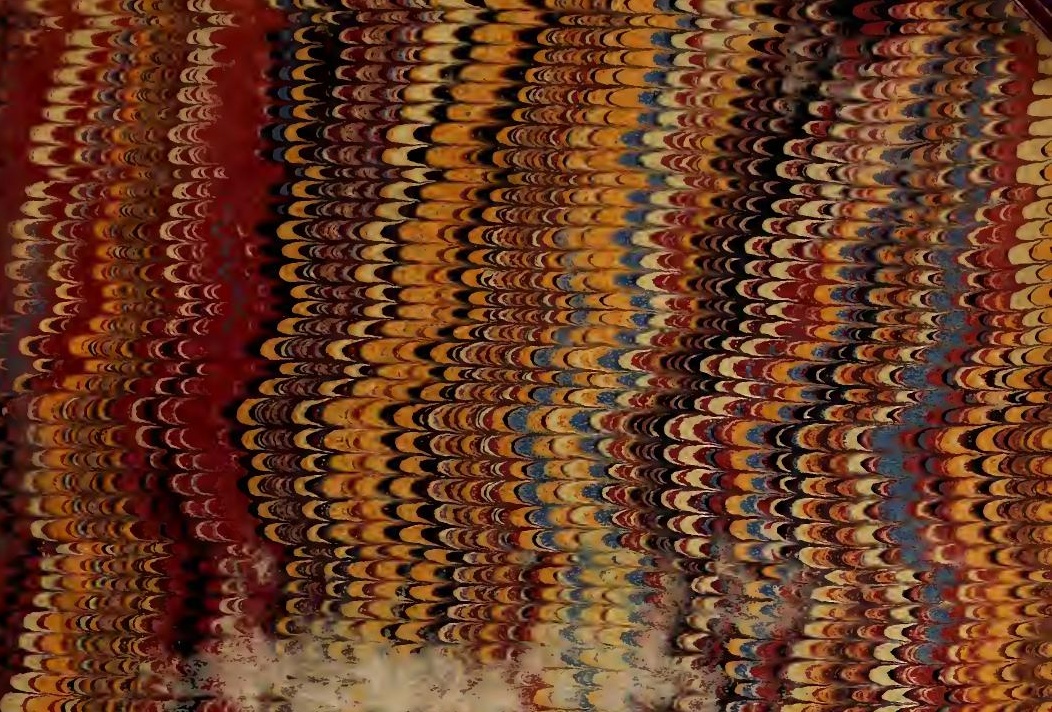

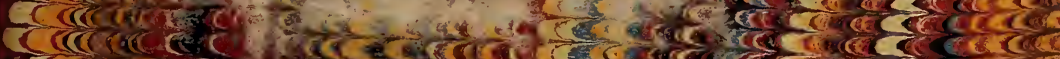

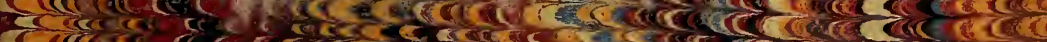

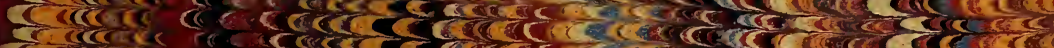

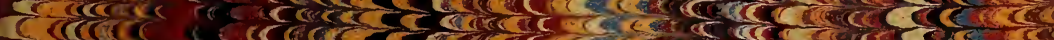
c secis $x$ बिद्ध

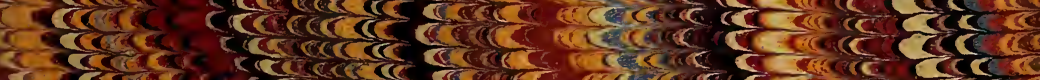

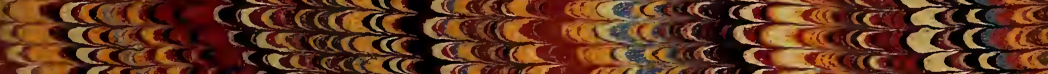

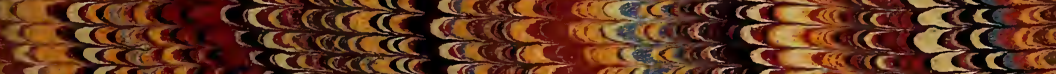

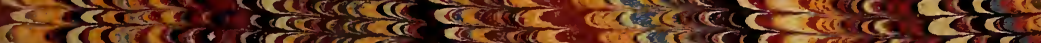
x-

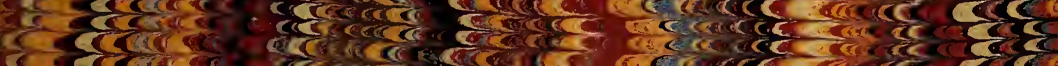

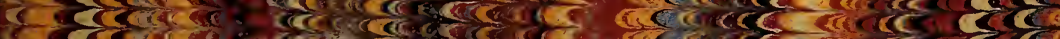

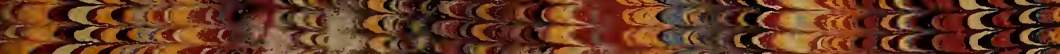

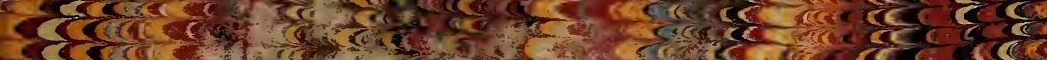

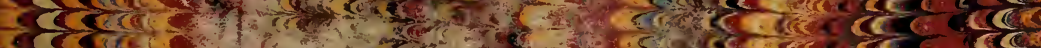

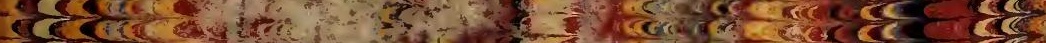
-

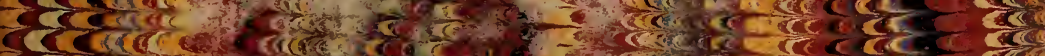

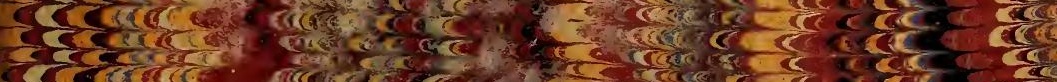

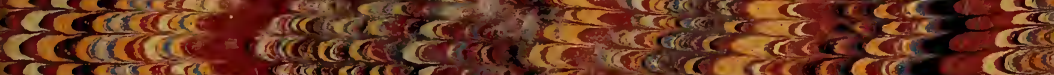

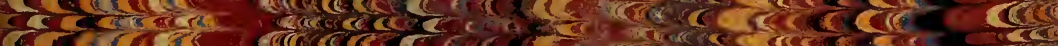

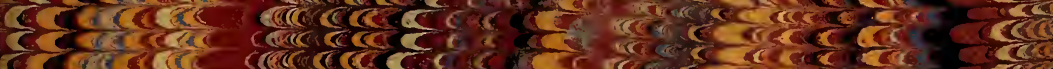

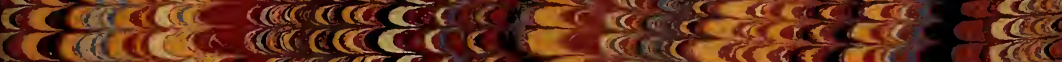

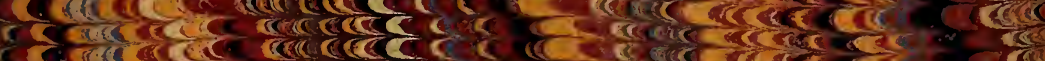

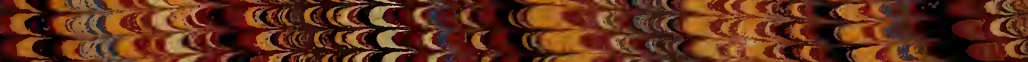

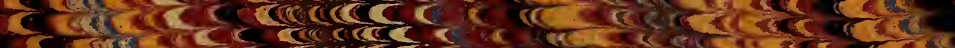

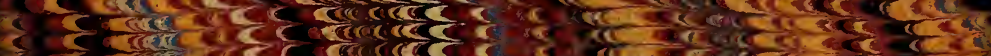

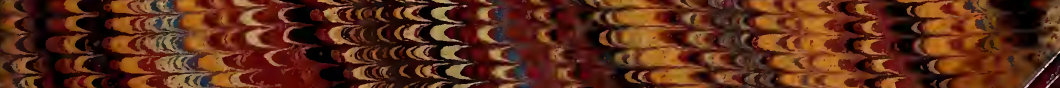

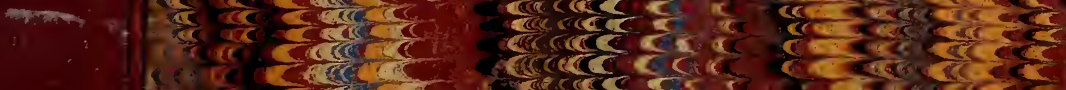

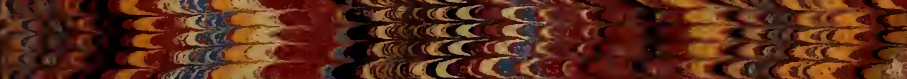

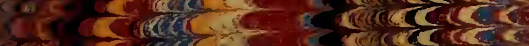

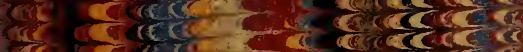
परेदी हों 


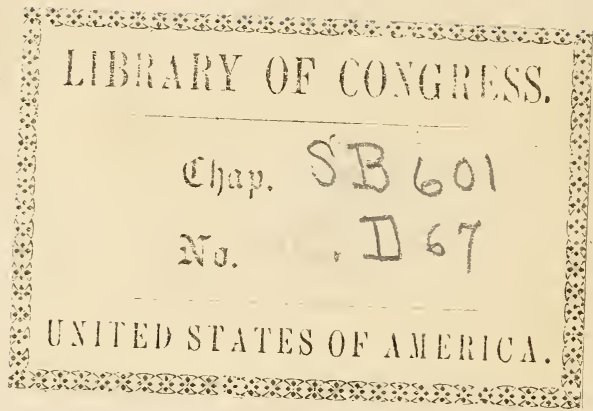






THE

\title{
ENEMIES TO AGRICULTURE,
}

\section{BOTANICAL AND ZOOLOGICAL;}

\author{
BEING A BRIEF ACCOUNT OF \\ THE WEEDS,
}

QUADRUPEDS, BIRDS, INSECTS, AND WORMS,

\author{
WHICH $A R E$
}

INJURIOUS TO THE FARMER,

WITH THE BEST MEANS OF

THEIR EXTIRPATION OR DIMINUTION,

\section{BY \\ JOHN DONALDSON,}

PROFESSOR OF AGRIOULTURE AND BOTANY AT HODDESDON, HERTS.

LONDON: ROBERT BALDWIN.

1847. 


$$
5^{30^{61}}
$$

LONDON:
GEORGE WOODFALL AND SON,
ANGEL COURT, SKINNER STREET. 


\section{0 N T E N T S.}

\section{PART I.-BOTAN ICAL.}

WEEDS.

Sect. I.-ON Tillage Land- Page

1. Chickweed-Stellaria . . . . . . . 4

2. Vernal sandwort-Arenaria verna : . : $\quad 6$

3. Corn spurrey-Spergula arvensis . . . . 7

4. Veronica hederifolia $. \quad . \quad . \quad . \quad . \quad .99$

5. Corn crowsfoot-Ranunculus arvensis . . . 10

6. Corn cockle-Agrostemma • . . . . 11

7. Corn poppy-Papaver Rhæas . . . . . 12

8. Wild mustard-Sinapis arvensis . . . . 13

9. Hedge mustard-Erysimum barbarea . . . 14

10. Gromwell-Lithospermum • . • . 16

11. Coltsfoot-Tussilago . . . . . . 17

12. Ragwort groundsel-Sonecio . . . . . 18

13. Sowthistle-Sonchus . . . . . . 19

14. Spearthistle-Carduus lanceolatus . . . . 20

15. Field-thistle-Carduus arvensis . . . . 21

16. The Dock-Rumex . . . . . . 22

17. Cornbind-Convolvulus arvensis . . . . 23

18. Knot grass-Polygonum aviculare . • . . 24

19. Fumitory-Fumaria . . . . . . 25

20. Rest harrow-Ononis . . . . . . 26

21. Fern-Pteris aquilina . . . . . . 27

22. Horsetail-Equisetum . • . . . . 28

23. Mouse-ear-Cerastium . • . • . . 29

24. Melilot-Trifolium melilotus . . . . . 30

25. Feverfew-Pyrethrum . . . • . . 30

26. Corn marygold-Crysanthemum . . . 31

27. Mint-Mentha . . . . . . . 32

28. Bluebottle-Centaurea . • . . . . 33

29. Corn chamomile-Anthemis . . . . . 34

30. Oat-like soft grass-Holcus avenaceus . . . 35

31. Wheat grass-Triticum . . . . . . 37

32. Wild oat-Arena fatua : $:$. . . $\quad . \quad 38$

Sect. II.-On Meadow or Pasture Land-

1. Cotton grass-Eriophorum . . . . 39

2. Hog weed-Heracleum . . . . . . 40

3. Wild cicely, or chervil-Chærophyllum . . . 41

4. Rush plant-Juncus . . . . . . 42

5. Tansey-Tanacetum $\quad . \quad$. $\quad . \quad$. 43

6. Yellow rattle-Rhinanthus : $: \quad . \quad: 43$

7. Yarrow, sneeze wort-Achilleæ $\quad . \quad \bullet^{\circ} \quad . \quad 45$

8. Pilewort-Ficaria . . . . . . . 46

9. Cud weed-Gnaphalium . . . . . . . 46

10. Marsh marygold-Caltha palustris $: \quad: \quad$. 47 
WeEds on Meadow or Pasture Iands-continued.

PAGE

11. Nettle-Urtica

12. Dandelion-Leontodon 48

13. Garlick-Allium . . 49

14. Lousewort-Pedicularis . . . . . . 50

15. Self-heal-Prunella . . . . . . . 51

16. Wild campion-Lychnis . . . . . . 52

17. Dyer's broom-Genista . . . . . . 52

18. Orchis . . . . 53

19. Eye-bright-Euphrasia . . . . . . 55

20. Sedge grass-Carex • • • • . . . 56

21. Black knap weed-Centaurea . . . . . 57

22. Wood anemone-Anemone nemorosa . . . 58

23. Water cowbane-Cicuta . . . . . . . 59

24. Meadow saffron-Colchicum . . . . . 60

25. Treacle mustard-Thlaspi . . . . . . 61

26. Goose tansy-Potentilla . . • . . . 62

27. Rushes-Juncus . . . . . . . 63

28. Docks-Rumex . . • • . . . 63

29. Bistort-Polygonum bistorta . • . . . 63

30. Rest harrow-Ononis . . . . . . 64

31. Thistles_Carduus . . . . • . . 64

32. Ox-eye-Chrysanthemum leucanthemum . 64

33. Crowsfoot plants-Ranunculus . . . . 64

34. Mint-Mentha . . . • . • . 65

35. Mouse-ear scorpion grass-Myosotis : : 65

36. Rag wort-Senecio Jacobea . . . . . . 65

37. Mosses-Musci • . • • • • • 65

\section{PART II.-ZOOLOGICAL.}

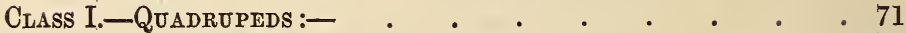

The Fox • • • • • • • • • 72

The Polecat . . . . . . . 75

The Hare • • • . • • • • • 77

The Rabbit . . . • . • . . 80

The Mole . . . . . . . . . . 82

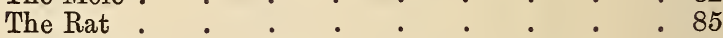

The Mouse $\quad$. $\quad . \quad$. $\quad . \quad$. $\quad$. 86

CLASS II.-BIRDS :-

The Rook . . . . . . . . . 88

The Pigeon $: \quad \div \quad \div \quad \div \quad \div 90$

The Woodpigeon $\quad \div \quad \div \quad \div \quad \div 91$

The Pheasant . . . . . . . . 92

CLASS III.-INSECTS :-

The Caterpillar. . . . . . . . 94

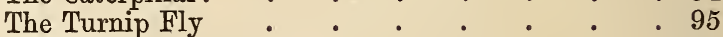

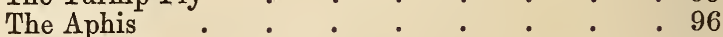

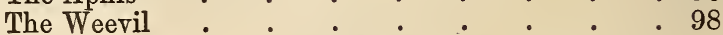

Class IV.-Worms :-

The Wireworm.

The Snail. $\quad . \quad \circ 100$ 


\section{ENEMIES TO AGRICULTURE.}

\section{PART I. BOTANICAL.}

\section{On the Weeds of Agriculture.}

A WEED is any plant that is useless for, or noxious to, any intended purpose in the production of vegetables. It has no definite application to any particular plant or species of plants; but whatever plants grow among corn, grass, or in hedges, and which are either of no use to man, or injurious to crops, are denominated "weeds;" and every plant which grows in a field other than that of which the seed has been sown by the husbandman, and inasmuch as it interferes with the intended crop, should be carefully eradicated. Farming is, that nothing grow on land except what is sown; and though this object may not be attainable, as there may ever be a wide difference between possible and ideal excellence, yet the nearer we approach to it the nearer we approach to perfection. And if it be absurd to expect perfection in any art or performance, there can be neither foolishness nor absurdity in making the nearest possible approaches to it.

Though the plants of nature which are called "weeds" are both useless and injurious to the purpose of the farmer, we must not suppose that on that account they have been created in vain, or that nature has used its efforts in producing useless objects. The mind that is capable of beholding the creation in a comprehensive and condensed focus, will arrive at a very different conclusion, and will not believe that any productions are useless, even those for which 
the discoveries of man have not yet found any application. It must not be imagined that the stores of nature are exhausted; and far less that the limited porvers of man are able fully to investigate and explain the nature and use of the numerous objects that catch his eye and engage his attention. Past and present experience have shown that the medicinal uses of weedy plants are very great; and from them are obtained the drugs that tend most powerfully to check and remove the disorders of the human frame. This one property very sufficiently vindicates their claim to a high place of utility, and rescues them from a useless degradation. When the vegetation has reached the maturity of full blossom, the structure forms a body of ligneous and vascular matter, which being used in decomposition, forms the very best manure that is yet known : for of all the ingredients that accessory science is daily bringing into use for the purpose of fertilizing the earth, and stimulating the growth of plants, no competitor has yet appeared that is capable of contesting the foremost place which decaying vegetable matters have held in the scale of manures, ever since the art of agriculture was practised by man. These two invaluable properties being duly considered, will convince that, when any production of nature is found to be useless for some specific purpose, or hurtful to any object that is desired to be attained, the conclusion must not be drawn, that it is on that account to be reckoned some careless or superfluous item thrown heedlessly from the lap of nature's bounty, and about which it has not exercised the provisionary and fitting aptitude that is so abundantly displayed in the stupendous magnificence and minute care that pervade every fabrication of nature's workshop. Nothing more powerfully tends to elevate the mind of man, than the contemplation of the works of nature; and profound and serious thoughts are very agreeably relieved by passing from the grand to the minute, there to admire, with equal adoration, the plastic hand that paints the crocus and the lilac, and which has essayed its art in heaving pile upon pile to form mountains almost to scale the vault of heaven. It is most pleasing and instructive to a contemplative man to 
observe and follow the graduated scale of natural objects that daily and hourly occur for observation and reflection, beginning with the lowly plants on which he treads, and which he may think are useless, and following the upward course of nature till he arrives at the utmost bounds of comprehension, and finally loses himself in immensity. Such a course of observation and reflection is most necessary in order to draw just conclusions about the works of nature, to raise the ideas above a mole-eyed plodding in the world's mud, and the clayborn sympathies and cold contemplations that are engendered by the mind being chained to the earth it inhabits.

The word "weed" must, therefore, be understood as a plant that is useless for a certain purpose, and for which a better agent has been found; and as being hurtful to another plant, which has been found to be the most valuable, yet known to yield the purpose that is desired; and that these plants are only useless and hurtful in the light in which we view them, or for the purposes of agriculture.

The tillage part of agriculture is formed entirely of a continual warfare between the cultivator and the weeds that grow on the land: and as in farming nothing should grow except what is sown, the efficiency of cultivation is judged by the presence or absence of the useless growths that appear on the ground. And as the removal of all useless vegetation is the main object of arable culture, a knowledge of the nature of the plants that are included in the name of "weeds" may prove useful when accompanied with a description of the easiest and most approved modes of eradication.

Weeds being many in number, some division or classification becomes necessary, in order to elucidate the subject, and relieve the memory. The most suitable arrangement appears to be into-I. Annual; II. Biennial; III. Perennial. The periods of their duration are thus distinguished, and there will be added the nature of the soil on which each plant is most abundant.

Annual weeds are such as die after perfecting the seeds in the first year. They produce seeds very abundantly, and on light soils give much trouble. 
Biennial weeds perish in the second year after perfecting the seeds. They are abundant in the production of seeds, as well as of plants, and are destroyed with greater difficulty than the former division.

The Perennial plants are such as exist for an indefinite period of time: some have the property of perfecting the seeds annually, without being thereby destroyed; while others, less prolific in seeds, have the faculty of reproduction in their vivacious roots; while others are capable of increase both by seeds and roots. The plants of this description are much more troublesome and difficult of destruction than the two former divisions.

For a practical description, the weeds of agriculture may be very conveniently divided into those that infest tillage lands, and the kinds that are found in pasture grounds; and a third may be added-those that grow in hedge-rows and plantations, and are occasionally found on cultivated lands.

\section{Sect. I.-Tillage Land Weeds.}

1. "Common chickweed," or "Stellaria Media" of botanists, is a very common weed on light loams that have been abundantly manured. This genus of plants has been called "Stellaria," from the star-like form of the flowers : it formed the "Alsine" of the older botany, and so called because the plant grows best in woods and shady places. Dr. Withering referred it to the "Stellaria," with which genus it agrees in various respects, and especially in the capsules opening with six valves. The British Flora also refers it to the genus "Stellaria," and characterizes it under the species "Media."

The genus "Stellaria" belongs to the class and order "Decandria trigynia" of Linneus, and to the natural order "Caryophylleæ" of Jussieu.

Generic character,-Calyx : perianth five-leaved; leaflets ovate-lanceolate, concave, acute, spreading, permanent. Corolla: petals five, two-parted, flat, oblong, shrivelling. Stamina : filaments ten, filiform, shorter than the corollaalternately longer and shorter; anthers roundish. Pistil: 
germs roundish; styles three, capillary spreading; stigmas obtuse. Pericarp : capsule ovate, covered, one-celled, sixvalved. Seeds very many, roundish, compressed.

Essential character.-Calyx five-leaved, spreading. Petals five, two-parted. Capsule superior, one-celled, manyseeded, six-toothed at top.

The species of common chickweed assumes very different appearances in different soils and situations : it thrives in all soils, from the damp and boggy woods to the driest gravelwalk in gardens, and is often seen with leaves near two inches long, and more than an inch broad, and the height sometimes exceeding half a yard. The number of stamens is uncertain : in damp situations, with a northern aspect, they amount to ten; and in drier soils, and in more sunny exposures, the number is usually three to five. The leaves are ovated, and the stalks procumbent, having the lateral line alternately hairy. When the flowers first open, the peduncles are upright; as the flowers go off, they hang down; and when the seeds ripen, they again become upright. The flowers open from nine in the morning till noon; but are shut during rain. They are pendent after rain; but, in the course of a few days, rise again. At night, the leaves approach in pairs, so as to inclose between their upper surfaces the tender buds; and the two upper leaves but one at the end of the stalk are furnished with longer petioles than the others, so that they can close upon the terminating pair, and protect the end of the branch. This is always mentioned as a very remarkable instance of the sleep of plants.

The "Stellaria media" is distinguished from the "Cerastiums" by the number of pistils, and by having the petals shorter than the leaves of the calyx; and particularly from the "Stellaria nemorum," by having the stalk alternately hairy on one side only. The young shoots and leaves, when boiled, can scarcely be distinguished from spring spinach, and are equally wholesome. Swine are very fond of it; cows and horses eat it; sheep are careless of it; and goats refuse it. It is a very grateful food to small birds and young chickens, and it is eaten by many insects. As a medicine, it was 
formerly used very extensively; but the application of it is now reduced to swellings, either alone or in poultices. The medicinal virtues are acknowledged; but the active matter is small in comparison with the grosser parts, and is very far divided and diluted in the herb.

The common chickweed is an annual plant, and flowers almost throughout the whole year. In gardens, on dunghills, and on soft, light loamy lands that have been abundantly manured, it grows luxuriantly, and sheds an abundance of seeds, which are round, compressed, yellow, and rough, with little tubercles, and thus becomes a troublesome weed. On soils that suit its temper, it is uncommonly tenacious of life; and if the weather be damp and showery, the roots immediately adhere to the soil, and the plant grows afresh, after being removed by the hoe and the scuffler. The great object is to prevent its perfecting any seed : but, as it grows almost during the whole year, the difficulty is almost insuperable. It is very hurtful to young turnips, clovers, carrots, and all slow-growing seeds. A close crop of vetches smothers it very readily. The most effectual way of clearing light lands from such a very troublesome weed, is to gather up the plants during dry weather, after being well shaken by the hand, and cleared from the adhering earth. The plant is naturally juicy and succulent; and, upon being laid into a heap, it quickly ferments and decomposes into an earthy mass. Cool earths may afterwards be added, as loam and effete lime, and a very good compost will be thus obtained. When the plant is pulled up by the hoe in order to be removed, it should be full grown, but before the seeds are formed.

2. The "Vernal sand wort," or "Arenaria verna," is a very troublesome weed on light moorish soils. The genus of plants is so called from the Latin word "arena," meaning "sand," in strict allusion to its native soil. It belongs to the class and order "Decandria Trigynia" of Linneus, and the natural order "Caryophylleæ" of Jussieu.

Generic character.-Calyx: perianth five-leaved; leaflets oblong, acuminate, spreading, permanent. Corolla : petals five, ovate, entire. Stamina: filaments ten, subulate 
(five alternately inferior); anthers roundish. Pistil : germ ovate; styles from erect, reflex; stigmas thickish. Pericarp : capsule ovate, covered, one-celled, three or six valved. Seeds very many, kidney-shaped. The number of stamens is not. constant.

Essential generic character-Calyx : five-leaved, expanding; petals five, entire. Capsule one-celled, many-seeded.

"The weedy species of the "Arenariæ" in Britain, is the "Arenaria verna," or "vernal sand wort." Leaves subulate, rather obtuse; stem panicled; petals obovate, longer than the calyx, three-nerved; nerves, distant, equal. Root perennial, long, much-branched. Stems numerous, five or six inches high, round, somewhat pubescent and viscid, branched at the base, and panicled above. Leaves erect, patent, subulate, rather obtuse, three-nerved beneath; and above, channelled, connate, and spreading at the base; bracteas ovate, short, three-nerved; peduncles erect, pubescent; leaflets of the calyx acute, hairy, three-nerved; margins membranous; petals longer than the calyx, obovate, obtuse; anthers fleshy; capsule longer than the calyx, cylindrical, three-valved; seeds almost kidney-shaped, rough, compressed. It flowers from May to August.

This plant does not grow so abundantly or luxuriantly as the "Stellaria media," and consequently it is less troublesome, and is much easier extirpated. It generally yields to the repetitions of the scuffler and the hoe; but when it is very abundant, it may be gathered off the land, as recommended in the case of " chickweed."

3. The "Corn spurrey," or "Spergula arvensis," is a plant of much notoriety, both as a weed, and in cultivation. The plant belongs to the class and order "Decandria pentagynia" of Linneus, and the natural order "Caryophylleæ" of Jussieu.

Generic character.-Calyx : perianth inferior, of five ovate, obtuse, concave, spreading, permanent leaves. Corolla: petals five, ovate, concave, spreading, undivided, larger than the calyx. Stamina : filaments ten, rarely but five, awl-shaped, shorter than the corolla; anthers roundish. Pistil: germen superior, ovate; styles five, somewhat reflexed, thread- 
shaped; stigmas thickish. Pericarp: capsule ovate, covered partly by the calyx, of one cell, and five valves. Seeds numerous, globose, but depressed, surrounded with more or less of a notched or dilated border.

Essential generic character.-Calyx of five leaves; petals five, undivided. Capsule superior, ovate, of one cell, with five valves.

This genus differs from the "Cerastium," in having undivided petals. Their general habit also differs more than is the case with most genera of this natural order, that of " Spergula" nearly according with various " Arenariæ," from which the five styles only distinguish it. The smooth-seeded spurrey has but five stamens.

The "Spergula arvensis," or " rough-seeded corn spurrey," is the most common species in Britain. Leaves in whorles, forming two bundles, about eight in each; stalks of the fruit reflexed. Seeds kidney-shaped, angular, rough. Root annual, small, fibrous. Herb more or less downy and viscid, very various in luxuriance, somewhat succulent and brittle, with a branched, round, loosely spreading stem, a foot in length, swelling globular, whose joints are beset with copious whorled, linear, obtuse leaves. Panicles many-flowered, terminal, forked, divaricated, level-topped. Flower stalks downy, strongly reflexed from the base, as the fruit ripens. Stipules in pairs at the joints. Calyx, membranous at the edge, nearly as long as the white petals. Stamens, generally ten, sometimes five, or some intermediate number. Capsule, almost twice as long as the calyx. Seeds numerous, kidney-shaped, or roundish, swelling, angular, with an obsolete, not dilated, nor membranous border; when ripe, they are black, and rough all over with minute tubercles or bristles. Poultry are fed with the seeds, and the herb serves as fodder over the continent of Europe.

"Spurrey" is a very troublesome weed on a light soil. It. flowers from July to September. The bulk is not great, nor the growth luxuriant; yet it is quick and very tenacious of life, and produces seeds in a very plentiful manner. In northern damp climates, whole fields of moorish light soils are so much infested with it, that the crop is often wholly de- 
stroyed. In such cases of an abundance of the plant, the gathering it off by hand-shaking, will be the most effectual mode of relieving the land from such a pest.

A larger variety of the "Spergula arvensis" is cultivated as excellent food for milch cows.

4. The "Veronica hederifolia" is a weed of importance on soft loams, and on land of a strength to produce both wheat and green crops.

The genus belongs to the class and order "Diandria monogynia" of Linneus, and the natural order "Pediculares" of Jussieu.

Generic character.-Calyx : perianth inferior, of one leaf, in four, rarely five, deep, lanceolate, acute, sométimes obovate, permanent segments. Corolla: of one petal, wheel-shaped. Tube almost as long as the calyx; limb, flat, in four deep, ovate, unequal segments, the lowermost narrowest, the opposite one broadest. Stamens: filaments two, inserted into the tube of the corolla, spreading, ascending, tapering downwards; anthers roundish, oblong. Pistil: germen superior, compressed; style thread-shaped, the length of the stamens declining; stigma simple, obtuse. Pericarp: capsule inversely heart-shaped, or somewhat elliptical, compressed in the upper part, of two cells, and two more or less cloven valves; seeds numerous, roundish.

Essential character. - Corolla four-cleft, wheel-shaped, the lower segment, narrowest. Capsule superior, of two cells.

The "Veronica" is a very natural genus, and an extensive one, extending to eighty-five species, which are commodiously and naturally arranged by their inflorescence.

The ivy-leaved "Speedwell," which we now mention as a weed, has the flowers solitary. Leaves heart-shaped, flat, and five-lobed. Segments of the calyx heart-shaped, acute. Seeds cupped, wrinkled. Root annual, small, fibrous. Flowers pale blue, on long, solitary, axillary foot-stalks. It is sometimes called "Small henbit;" and in Norfolk the name is "Winter weed."

This plant flowers in April and May, and seldom later. It 
is a native of Europe and Barbary, and grows in gardens, fields, and waste grounds. The presence of it is not very troublesome, and it yields readily to cultivation by the hoe and the scuffler.

5. The "Ranunculus arvensis," or "Corn crowsfoot," is a very common weed on clay lands, which have an upper soil of a soft damp nature. The plant belongs to the class and order "Polyandria polygynia" of Linneus, and the natural order "Ranunculaceæ" of Jussieu.

Generic character.-Calyx : perianth, of five ovate, concave, somewhat coloured, deciduous leaves. Corolla : petals five, obtuse, polished, with small clawed nectary, a cavity in each petal, just above the claw. Stamina: filaments very numerous, half the length of the corolla; anthers firmly united therewith, erect, oblong, obtuse, of two separate lobes. Pistil : germens numerous, collected into a head; styles none; stigmas reflexed, very small. Pericarp none. Receptacle beset with extremely minute stalks, to which the seeds are attached. Seeds numerous, naked, irregular, uncertain in figure, with a reflexed point.

Essential character.-Calyx five-leaved. Petals five to eight, with a honey-bearing pore in the claw of each. Seeds naked.

The most essential mark of this genus is the nectary; the rest of the parts being uncertain. The nectary is, in some species, a naked pore; in some, it is bordered with a cylindrical margin; in others closed with a notched scale.

The "Ranunculus arvensis," or "Corn crowsfoot," has the root annual and fibrous. Stem one or two feet high, much-branched, many-flowered, leafy, nearly smooth. Leaves of a light green colour, slightly hairy, stalked, once or twice ternate, as well as deeply three-cleft; the ultimate segments almost linear, entire, or rarely notched. Flowers small, lemon-coloured, stalked, lateral and terminal. Calyx spreading, hairy. Petals obovate, veined. Fruit depressed. Seeds very large, compressed, with erect, awl-shaped, hooked beaks, their sides armed with numerous prominent awl-shaped prickles, largest towards the margin. 
The genus "Ranunculus" is very extensive, reaching to eighty-five species; fifteen are natives of Britain. The species are all herbaceous, generally of an acrid quality. The prevailing colour of the flowers is yellow. They grow in cold temperate climates, and some of the plants are Alpine. The whole genus is very conveniently divided into two sections, by the form of the leaves.

The species which we now notice as a weed, is one of the most virulent of its genus, especially when young; causing inflammations and gangrene in the stomachs of sheep and oxen, although it is eaten by them with great avidity. The expressed juice of the plant is also fatal.

The Ranunculus produces seeds in great abundance, and the corn crowsfoot being an annual plant, nature has furnished it with the prolific seed-bearing quality which attaches to the plants of that period of duration, in order to compensate for the short existence of the stem. No process of summer fallowing can kill the numerous seeds; and as the lands on which it grows are not suitable for drilled green crops, there becomes a necessity that the wheat crops be drilled, in order to give an opportunity of pulling the plants by hand at the time when they are in full blossom, and when no seed has been formed. It is frequently called "Hunger weed," probably from its growing on the poorer soils.

6. The "Corn cockle," or "Agostemma" of botany, is a common weed in corn fields, mostly on clayey loams, or the more loamy wheat fallows. It belongs to the class and order "Decandria pentagynia" of Linneus, and to the natural order " Caryophylleæ" of Jussieu.

Generic character.-Calyx: perianth one-leaved, coriaceous, tubulous, five-toothed, permanent. Corolla: petals five, claws the length of the tube of the calyx ; border spreading, obtuse. Stamina : filaments awl-shaped, five alternately later than the other five, inserted into each claw of the petals ; anthers simple. Pistil: germ ovate; styles filiform, erect, the length of the stamens; stigmas simple. Pericarp: capsule oblong, ovate, covered, one-celled, five-valved. Seeds very many, kidney-shaped, dotted; receptacles three, as many as seeds; the interior ones gradually longer. 
Essential character. - Calyx one-leaved, coriaceous; petals five, clawed border, obtuse, undivided. Capsule onecelled.

There are four species, of which the "Agostemma githago," or the "Corn cockle" or campion, is the common British plant. It is hirsute or hairy. Calyx longer than the corolla; petals entire, or slightly emarginate, and naked. It flowers in June and July, and has a very beautiful appearance. The seeds ripen about the time of harvest; and from the size, they cannot be easily separated from the corn in sifting; the farina is oily, and when ground with the corn, it greatly deteriorates the flour. The only mode of extirpation is by hand-weeding, and by drilling the grain crops for that purpose.

7. The "Corn poppy," or "Papaver rhæas" of botany, infests some soils at particular seasons. It belongs to the class and order "Polyandria monogynia" of Linneus, and the natural order "Papaveraceæ" of Jussieu.

Generic character.-Calyx : perianth inferior, ovate, emarginate, of two nearly ovate, concave, obtuse, immediately deciduous leaves. Corolla: petals four, roundish, flattish, spreading, large, contracted at the base, alternately smaller. Stamina: filaments numerous, capillary, inserted into the receptacle, much shorter than the corolla; anthers oblong, compressed, erect, obtuse. Pistil : germen superior, sessile, large, roundish; style none; stigma depressed, peltate, flat, radiated. Pericarp: capsule oval, or somewhat oblong, crowned with the large, flat, permanent stigma of one cell, though imperfectly divided into many, bursting at the top by numerous orifices under the stigma. Seeds numerous, minute; receptacles, longitudinal folds, attached to the inside of the capsule, equal in number to the rays of the stigma.

Essential character.-Calyx of two leaves; petals four; stigma radiated. Capsule superior, of one cell, opening by pores under the permanent stigma.

There are two divisions of the poppy plant, with the capsules bristly and smooth. The common "red poppy," or the "corn rose," belongs to the second section. The capsules are smooth, nearly globular. Stem many-flowered, rough, with horizontal hairs. Leaves pinnatifid, cut. The 
root is annual. Stem about two feet high, branched, clothed all over with bristly hairs, that all spread horizontally. Leaves pinnatifid, often in some degree bi-pinnatifid, their segments oblong, serrated, and cut, more or less hairy. Flowers slightly fetid, and of a deep and most brilliant scarlet-red colour. Capsule quite smooth and even, short and abrupt, with a many-rayed stigma.

The poppy flowers in June and July, and perfects a profusion of seeds. It delights to grow on waste grounds, and on badly managed cultivated fields; good tillage soon destroys it; clover and tares, which are cut while the poppy is in flower, generally eradicate it. It will increase rapidly, if the seeds be allowed to ripen; in some seasons the plant appears in great abundance, and in others, not a plant will be seen.

8. The Wild mustard, or "Sinapis arvensis," is an annual weed of much annoyance on some of the best soils. The "Sinapis" belongs to the class and order "Tetradynamia siliquosa" of Linneus, and the natural order "Cruciferæ" of Jussieu.

Generic character.-Calyx: perianth inferior, spreading, divided into four linear, concave, channelled leaves, forming a cross, deciduous. Corolla cruciform, of four rounded, flat, spreading, undivided petals, with erect, linear claws, scarcely the length of the calyx. Nectary composed of four ovate glands, one on each side, between the shorter stamen and the pistil, and one each side between the longer stamen and the calyx. Stamina: filaments six, awl-shaped, erect, the two shorter ones opposite; anthers erect, spreading, pointed. Pistil : germen superior, cylindrical; style the length of the germen, and height of the stamens; stigma capitate, undivided. Pericarp: pod oblong, inflated unequally at the lower part, rough, of two cells, and two valves; partition generally twice as long as the valves, large, compressed. Seeds numerous, globular.

Essential character.-Calyx widely spreading; claws of the petals straight; nectariferous glands, four; pod more or less cylindrical; the partition longer than the valves. 
The "Sinapis" differs chiefly from the "Brassica," or turnip plant, in having a spreading calyx, and the claws of the petals erect.

The "Sinapis arvensis" has the root annual, fusiform. Stem, from nine inches to a foot and a half in height, upright, rough, with a few stiff hairs or bristles, bent somewhat downwards. Branches spreading. Leaves petioled, rugged, serrate, sometimes entire, but most frequently jagged at the base, and sometimes lyrate or pinnatifid. Flowers at the end of the stem and branches, in a clustered corymb, each on a pedicle the length of the calyx, and slightly hispid. Corolla always yellow. Siliques spreading, slightly hairy, or sometimes smooth, torose or swelling, ending in a short, compressed, ensiform, grooved beak. Seeds dark brown, shining, eight or nine, extremely pungent, and well known under the name of "Durham mustard." It flowers in June and July, but occasionally in all open weather, and forms a very troublesome weed on heavy moist corn lands. The seeds are of an oily nature, and remain dormant in the soil for an indefinite time, if buried below the depth of six inches. On being brought by deep ploughing near the light, the plants appear in such abundance as to overrun and smother any growing crop. They may be destroyed before seeding, and winter tares being cut when the flower is in blossom, will much help to destroy it; and if a crop of turnips follows the tares, the charlock will be well-nigh destroyed. The crops being drilled, the blossomed plants must be pulled by hand, and carried from the field; for the seeds, if only half perfected, will grow with much readiness.

The classical name in English, is "Wild mustard ;" but it is variously called, in provincial language, charlock, garlock, warlock, chadlock, cadlock, and kedlock. The young plants, and particularly the tender tops before they flower, are boiled, and eaten as greens by the peasants in Scandinavia, Ireland, and many parts of England.

9. The "Hedge mustard," or "Erysimum barbarea" of botany, is a weed of much frequency on similar soils with the last, and being like it in appearance, the two plants are often 
confounded. The plant belongs to the class and order "Tetradynamia siliquosa" of Linneus, and the natural order "Cruciferæ" of Jussieu.

Generic character.-Calyx : perianth four-leaved. Leaflets ovate, oblong, parallel, converging, coloured, deciduous. Corolla: four-petalled, cruciform; petals oblong, flat, extremely obtuse at the tip; claws, length of the calyx, upright; nectariferous gland, double, within the shorter filament. Stamina: filaments six, length of the calyx, of these the two opposite shorter; anthers simple. Pistil: germ linear, four-cornered, length of the stamens; style very short; stigma headed, permanent, small. Perianth : silique long, linear, strict, exactly four-cornered, two-valved, two-celled. Seeds very many, small, roundish.

Essential character.-Silique colunnar, with four equal sides. Calyx closed.

The "Erysimum barbarea," or the winter cress or hedge mustard, has the leaves lyrate, the outmost lobe roundish. Root perennial. Stem a foot or eighteen inches bigh, smooth, round, deeply furrowed, much-branched. Leaves smooth, dark green, having two or three pairs of roundish lobes, connected to a broad foliaceous rib, the extreme lobe much the largest, and either of an oval or blunt rhomboidal figure, slightly indented on the edges, but they vary much in form. Flowers in racemes or thick spikes at the ends of the stem and branches ; calyx green; petals yellow, much longer than the calyx. Seeds roughish, finely dotted and reticulated, twenty in number, ten in each cell.

This plant flowers in May to July. It grows in watery places, on banks of ditches and streams, on walls, and in cultivated fields. The leaves are used as salads, and also boiled as "kale." The taste is mostly bitter and unpleasant, and the whole plant has a nauseous, bitter, slimy flavour. The dark shining broad leaves distinguish it from the "mustards," with which it is frequently confounded; they grow intermixed, the colour of the flowers is similar, and the unaccustomed eye mistakes the one for the other. The lower leaves are lyrate, with the terminal lobe rounded; upper ones obovate, 
toothed. This characteristic separates it from the "Sinapis." The same means of eradication apply to both plants.

10. The "Gromwell," or the "Lithospermum" of botany, is a plant of frequent growth on soft lands on a clayey bottom, mostly adapted for wheat. The plant belongs to the class and order "Pentandria monogynia" of Linneus, and the natural order "Boragineæ" of Jussieu.

Generic character.-Calyx : perianth five-parted, oblong, straight, sharp, permanent; divisions awl-shaped, keeled. Corolla one-petalled, funnel-form, length of the calyx; tube cylindric; border half five-cleft, obtuse, upright ; throat perforated, naked. Stamina : filaments five, very short; anthers oblong, incumbent, covered. Pistil: germs four ; style filiform, length of the stamens; stigma obtuse, emarginate. Pericarp none; calyx grown larger, upright, containing the seeds in its bosom. Seeds four, rather oblong, obtuse, gibbous.

Essential character.-Calyx five-parted. Corolla funnel-form, perforated at the throat, naked.

The "Corn Gromwell," or the "Lithospermum arvense," has the seed ovate, wrinkled; calycine leaflets, lanceolate; corollas, scarcely longer than the calyx. Leaves lanceolate, sharpish, hispid. Root annual, small, and not muchbranched; the bark abounds with a deep red dye, which stains paper and linen. Stem upright, a foot or more in height, round or slightly angular, rough, with close-pressed hairs, often much-branched at the top. Leaves alternate, lanceolate, entire, rigid, sessile, rough, with bristly hairs close-pressed standing out from the edge. Flowers solitary, nearly sessile, in the axils of the upper leaves. Corolla small and white, with five swellings round its orifice. Seeds brown, rugged, rather covered with hard tubercles than wrinkled; two, three, or four, but generally three, with one abortive; when there are four seeds, two are found abortive, and six divisions in the calyx.

This plant flowers from May to July, and in some places it is pretty abundant. Being annual, the seeding only has to be guarded against; and the wheat crops being drilled, 
the blossomed plants must be pulled by hand. The seeds are not numerous; and a well-executed summer fallowing of the land, will do much in eradicating the tribe of sparingly seeded plants.

11. The "Coltsfoot," or the "Tussilago" of botany, is a plant of much frequency on damp clayey loams, that are adapted for the green crop cultivation. It belongs to the class and order "Syngenesia Polygamia Superflua" of Linneus; and the natural order "Corymbiferæ" of Jussieu.

Generic character.-Calyx, common cylindrical. Scales, lanceolate, linear, (fifteen or twenty), equal, as long as the disk, submembranaceous. Corolla compound, various. Corollets in some are hermaphrodite and tubular, or only in the disk. Females in some none, in others ligulate. Proper of the hermaphrodite, funnel-formed, border fivecleft (or four-cleft), acute, reflexed, longer than the calyx. Females none, or ligulate, very narrow, longer than the calyx, entire. Stamina: in the hermaphrodites, filaments five; capillary very short; anther cylindric, tubular. Pistil in the hermaphrodites, germ short. Style filiform, longer than the stamen. Stigma thickish. In the females, germ short; style filiform, length of the hermaphrodite; stigma bifid, thickish; pericarp none; calyx scarcely changed. Seeds in the hermaphrodites, solitary, oblong, compressed. Down capillary, stipulate. In the females, if any, like the others. Receptacle naked.

Essential character.-Calyx, scales equal, as long as the disk, somewhat membranaceous. Down simple. Receptacle naked.

The common or field species of coltsfoot is the "Tussilago Farfara." Scape one-flowered, scaly-leaves, cordate, angular, toothletted. Root perennial, creeping horizontally, far and wide. Flowers solitary, terminating, yellow, more conspicuous on account of their radiate form than most of the other species. The flowers come up early in the spring before the leaves, and at some distance from them; they are upright, but as soon as the bloom is past, and the seeds, with their down as yet moist, are inclosed within the calyx, the 
heads hang down; as the moisture evaporates in ripening they become lighter, are again erected, and the down expands.

The "coltsfoot" is often a very troublesome weed in moist, stiff clayey, and marley soils, that have been overcropped and exhausted. The roots penetrate deeply, and are widely spread, and when drawn they often break, and sprout again very vigorously. To eradicate roots of that nature, deep ploughing is the surest way; and the furrow must be comparatively narrow, in order that the roots may not escape unhurt between the furrow slices. The root being perennial, renders attention to the eradication of that part of the plant equally if not more necessary, with the prevention of the seeds being perfected. Both duties being properly executed, the "coltsfoot" will speedily disappear, the presence of it being a sure mark of bad management.

12. The "Ragwort," or the "Senecio" of botanists, is a very common weed in Britain, and grows in most soils and situations. The plant belongs to the class and order "Syngenesia Polygamia Superflua" of Linneus, and the natural order "Corymbiferæ" of Jussieu.

Generic character.-Common calyx, calyculate, conical, truncated. Scales awl-shaped, numerous, parallel and contracted into a cylinder at the upper part, contiguous, equal; not so numerous at the base, but imbricated, withering at the tip. Corolla compound, higher than the calyx. Florets of the disk perfect, tubular, numerous, funnelshaped, with a five-cleft, reflexed limb; those of the radius, if any, female, ligulate, oblong, slightly three-toothed. Stamina: in the perfect florets, filaments five, capillary very small; anthers cylindrical, tubular. Pistil (in all the florets), germen ovate; style thread-shaped, the length of the stamens; stigmas two, oblong, revolute. Pericarp none, except the conical, converging calyx. Seeds in both kinds of florets alike, solitary, ovate, crowned with capillary long down. Receptacle naked, flat.

Essential character.--Receptacle naked. Down simple. Calyx cylindrical, many-leaved, equal, scaly at the base. Scales dead at the tip. 
The "Senecio vulgaris," or the "common groundsel," belongs to the first section of the genus. "Flowers without a radius." Scattered. Leaves situated in a pinnate form, toothed, embracing the stem. Root annual, fibrous. Stem erect, branched, leafy, somewhat panicled, round, angular, either smooth or clothed with a cottony down like the back of the foliage. Leaves alternate, bright green, radical ones, stalked, those of the stem sessile, auriculate. Flowers terminal, scattered or panicled, yellow. Seeds furrowed, pubescent. Seed-down sessile, rough. The great peculiarity in the genus "Senecio," of having the scales of the calyx withered, is very conspicuous in the present species, whose flower-buds and young-tops are the food of many small birds, both wild and domestic.

The "common groundsel" flowers throughout the year, almost in any soil or situation. It delights most in soft damp situations, as compost heaps of earths, or lands of the above texture. The root being annual, it only remains to prevent the seeds being perfected, by very careful and repeated hoeings and scufflings of the drilled crops. Where such weeds are very numerous, the best way is to cut them with the hoe when in full flower, and carry them off the field.

13. The "Sowthistle," or the "Sonchus" of botanists, sometimes grows luxuriantly among corn crops. The plant belongs to the class and order "Syngenesia Polygamia Equalis" of Linneus, and the natural order "Cichoraceæ," of Jussieu.

Generic character.-Common calyx imbricated, bellying, of numerous, linear, unequal scales. Corolla compound, imbricated, uniform. Florets all perfect, numerous, equal, of one petal, ligulate, linear, abrupt, with five teeth. Stamina, filaments five, capillary very short; anthers united into a cylindrical tube. Pistil germen nearly ovate; style thread-shaped, the length of the stamens. Stigmas two, reflexed. Pericarp none, except the calyx, closing into the form of a depressed globe, with a conical point. Seeds solitary, rather oblong. Down capillary, sessile. Receptacle naked. 
Essential character.-Receptacle naked. Calyx imbricated, swelling at the base. Seed-down simple, sessile.

The "Sonchus arvensis," or the "Corn sow-thistle," is a frequent weed in damp loams. The root is creeping, fleshy and milky, running deep into the ground, and difficult of extirpation.

The "Sonchus oleraceus," or the common "Sow-thistle," is much more frequent than the former species, and is a very common weed on cultivated lands. Flower stalks downy, imperfectly umbellate. Calyx smooth. Leaves runcinate, toothed. Root annual, spindle-shaped. Herbage smooth, brittle, milky; very various with respect to luxuriance, and the number of teeth, lobes, or prickles about the edges of its leaves; their segments, however, are almost always acute and runcinate. Flower stalks axillary and terminal, rather cymose than umbellate, clothed when young with soft, white, dense, cob-web-like deciduous down. Corolla lemon-coloured. Seeds angular, with crenate ribs.

"Thistles" are easily eradicated by a careful tillage in killing the roots, and by preventing the perfection of the seeds in cutting the stems when the flowers are in blossom. The seeds are numerous, and are easily carried about by the wind, and consequently no plants should be allowed to grow on the hedge-sides and in ditches, for lanes and road sides often produce seeds to infest the adjoining fields.

14. The "Spear thistle," and the "common field thistle," belong to the genus "Carduus," one of the most extensive in the vegetable kingdom. It belongs to the class and order "Syngenesia polygamia equalis" of Linneus, and the natural order "Cinarocephalæ" of Jussieu.

Generic character.-Calyx common, ventricose, imbricate; scales very numerous, lanceolate, acuminate, spiny. Corolla compound, tubular, uniform. Corollules hermaphrodite, subequal, reflected; the proper one monapetalous, infundibiliform; tube very slender; border erect, ovate at the base, quinquefid; divisions linear, equal, one more deeply serrated than the rest. Stamina: filaments five; capillary very short; anthers cylindrical, tubular, length of the corollule, five- 
toothed at the mouth. Pistil: germ ovate; style filiform, longer than the stamens; stigma simple, subulate, naked, emarginate. Pericarp none; calyx converging a little. Seeds solitary, obovate, four-cornered, the two opposite corners obliterated; down sessile, very long. Receptacle hairy, flat.

Essential character.-Calyx ovate, imbricate with spiny scales; receptacle hairy.

The "Spear thistle," or "Carduus lanceolatus," is sometimes seen on corn fields, but more generally on ditch banks and the sides of hedges. Leaves decurrent, pinnatifid, hispid; divisions divaricate; calyxes ovate, spiny, villose. Stem hairy. Root biennial; stem upright, three or four feet high, angular, downy, and sea-green underneath; hairy, and deep green above. Flowers in July. It is often called the "burthistle." The flowers have the property of curdling milk.

The means of eradication are cutting and pulling the stem, and using the most diligent attention that no seeds be perfected. If cut in the early season, side branches will shoot and perfect seeds, so that a second cutting is required; but, if allowed to grow to height, one cutting will be sufficient. Every plant in lanes, road-sides, ditch-banks, and in the roots of hedges, should be very carefully destroyed, for the seeds are winged with down, and are easily carried by the wind to distant places, where they alight and grow.

15. The "Field thistle," or "Carduus arvensis," is placed in the second section of the species, having the leaves "not decurrent." The leaves are sessile, pinnatifid, spinous-stem, panicled; calyxes egg-shaped, slightly spinous, down feathery. Root perennial, creeping, tapering, descending deep into the ground,-not easily extirpated. Stems three feet high, erect, round, smooth, many-flowered. Leaves slightly decurrent, alternate, smoothish; lobes unequal, ciliated, spinous. Flowers white; calyx egg-shaped; scales broad lanceolate, pressed close; woolly at the edges, with a short spreading spine; down deciduous; root permanent.

The permanent root remaining in the ground, and sending up flowering stems in succession, is the chief tendency to be 
guarded against in the "common thistle;" the stems can be kept down by repeated cuttings. In order to eradicate the tapering and spreading, no process is so effectual as "deep ploughing," executed with a strength of four horses, and the furrow narrow in proportion to the depth, that no roots escape uncut between the furrow slices. This mode of deep and narrow ploughing never fails in completely expelling the thistle as a weed on cultivated grounds.

16. The common "Dock," or the "Rumex" of botanists, is a very annoying weed both in cultivated lands and on pastures, in soft damp soils. It belongs to the class and order "Hexandria trigynia" of Linneus, and the natural order "Polygoneæ" of Jussieu.

Generic character.-Calyx : perianth, three-leaved; leaflets obtuse, reflex, permanent. Corolla: petals three, ovate, bigger than the calyx, and, like it, converging, permanent. Stamina : filaments six, capillary very short; anthers erect, twin. Pistil : germ turbinate, three-sided; styles three, capillary reflexed, standing out between the clefts of the converging petals; stigmas large, laciniate. Pericarp none. Corolla converging, three-sided, inclosing the seed. Seed single, threesided.

Essential character.-Calyx three-leaved; petals three, converging. Seed one, three-sided.

The "Rumex obtusifolius," or "Blunt-leaved dock," is the most common weed. Flowers hermaphrodite; valves toothed, one chiefly graniferous root. Leaves cordate, blunt. Stem somewhat rugged. Root tapering, running deep and straight. Stem three feet high, upright, branched. Racemes nearly upright, furnished with few leaves. Flowers in half whorls, on capillary peduncles, sprinkled near the top with white shining globules, and the pedicles surrounded near the base by an indistinct cartilaginous ring.

The "Rumex acetosa," or the "Common sorrel," has a perennial root, running deep into the earth. Stem mostly simple, erect, from one to two feet high. Flowers dioecous ; valves graniferous. Leaves oblong, sagittate. It flowers early in June. 
The "Rumex acetosella," or "Sheep's sorrel," is less than the common sorrel by half. Root creeping, perennial. Flowers dioecous; valves grainless. Leaves lanceolate, hastate.

The presence of any plant of the dock tribe on arable or pasture lands, shows a moisture which requires draining to carry it away, and the appearance of the sorrels indicates a sourness which requires the application of calcareous matters to remove it. And in case of all permanently rooted plants, deep and clear ploughings are again recommended for the purpose of eradicating them.

The "Dock" ripens an abundance of seeds, which are shed round the parent, not having the means of being dispersed to any great distance. The seeds are very tenacious of life, and nothing but burning is a sure destruction of them. The roots are equally tenacious, and require to be removed from the field on being pulled up. The roots send forth new shoots from almost any depth.

17. The "Cornbind weed," or the "Convolvulus arvensis" of botany, is found occasionally growing among wheat, and twining round the stalks of corn. The plant belongs to the class and order "Pentandria monogynia" of Linneus, and the natural order "Convolvulaceæ" of Jussieu.

Generic character.-Calyx : perianth five-cleft. Corolla : monopetalous, bell-shaped, or funnel-shaped, plaited; border generally spreading, more or less five-lobed. Stamina: filaments five, awl-shaped, shorter than the corolla, approximating at the base. Pistil: germen superior, roundish; style filiform; stigma simple or bifid. Pericarp: capsule surrounded by the calyx, roundish, one, two, three, or four-celled; one, two, three, four, or many-valved. Seeds one or two in each cell.

Essential character.-Calyx five-cleft. Corolla bell or funnel-shaped; stigmas one or two. Pericarp: a capsule or dry berry. Seeds one or two in each cell.

The calyx is often called "five-leaved," when it is very deeply "five-cleft."

The common field bind-weed is a native of Britain and 
most parts of Europe. Leaves arrow-shaped, lobes acute. Flowers generally solitary; bractes, minute, awl-shaped, remote from the flower. Root perennial, creeping, striking deeply into the ground, not easily extirpated. Stems numerous, angular. Leaves alternate, petioled, smoothish. Flowers flesh-coloured, sometimes white, sweet-scented, opening only in clear weather; peduncles axillary, generally one-flowered, thickened above. The juice is slightly purgative, and the blossoms give a deep orange or yellow tincture to water, which is heightened by alum and alkalis. It flowers in June and July.

This weed is most common on dry gravelly soils, where it wanders over whole fields, twining round the stalks of the grain, and very much injuring the crop, especially when it has been laid by heavy rains. The roots run deeply and very widely. It brings plants to the ground, or checks their vegetation, by injuring their structure. Being perennial, it must be rooted out by repeated ploughings done in dry weather, and by carefully picking off the roots and burning them. The roots are very vivacious, and the smallest bit left in the ground will spring and rise to the surface.

18. "Knot-grass," or the "Polygonum aviculare" of botany, is not an uncommon weed on tillage lands. The plant belongs to the class and order "Octandria triginia " of Linneus, and the natural order "Polygoneæ" of Jussieu.

Generic character.-Calyx : perianth inferior, of one-leaf, turbinate, internally coloured, in five deep ovate, obtuse, permanent segments. Corolla none, unless the calyx be taken for such. Stamina: filaments generally eight, awl-shaped, very short; anthers roundish, incumbent. Pistil : germen superior, triangular; styles mostly three, thread-shaped, very short; stigmas simple. Pericarp none, the calyx folding over the seed. Seed one, acute, with three, rarely only two angles.

Essential character.-Calyx : in five deep segments, coloured, petal-like, permanent. Seed one, superior, angular, covered by the calyx; stamens and styles uncertain in number. 
The most common species is called "Aviculare," from the gratefulness of its seeds to small birds; it grows in great abundance on road sides, on sandy and gravelly soils, and also on cultivated fields, and covers much ground where the natural plants have been destroyed. The flowers are axillary; styles three. Leaves elliptic, lanceolate, rough-edged. Ribs of the stipules remote. Stem procumbent, herbaceous. The crimson flowers are very numerous, and very beautiful under a magnifier. The root is annual, and of an astringent taste, and once reckoned of some medical virtue, but now wholly superseded. All quadrupeds are fond of the plant, and hence it is called "knot-grass," though it bears no resemblance to the real grasses.

The seeds are numerous, and the habits are trailing, and the mode of extirpation consists in preventing its seeding, by a timely cutting of the plants. It is not among the most troublesome weeds.

The " Blackbind weed," or the "Polygonum convolvulus," is often found as a weed on cultivated fields. It is annual, and twines round the stems of plants to the height of three feet or more, with a stem roughish, angular, and somewhat branched. The prevention of the seeds being perfected, by means of a careful and constant culture, is the sure means of eradication.

19. "Fumitory," or the "Fumaria" of botany, is a common and very abundant weed on soft loams of the best quality. The plant belongs to the class and order "Diadelphia hexandria" of Linneus, and the natural order "Papaveraceæ" of Jussieu.

Generic character.-Calyx : perianth inferior, of two equal, small leaves, mostly deciduous, often coloured. Corolla tubular, ringent, of two petals, each lobed, and spreading at the extremity, gibbous, and holding honey at the base, variously formed in different species. Stamina: filaments six, capillary, united into two sets by their broad, elongated, membranous bases, sheathing the germen; anthers small, roundish, vertical. Pistil: germen roundish or oblong; style curved or oblique; stigma obtuse. Pericarp: 
pod of two valves, and one cell. Seeds one or more, roundish.

Essential character. - Calyx of two leaves, inferior. Corolla: ringent, gibbous, and honey-bearing at the base, each filament bearing three anthers.

The "Common fumitory," or the "Fumaria officinalis," flowers from April to August, and later, with very elegant pink blossoms, variegated with spots of dark red, and of green. Pericarps one-seeded, racemed. Stem diffuse; it is annual, but not reckoned a very troublesome weed, though often very abundant on good soft loams. After being cut by the hoe in the drills, the plants should be carried off the field; as in damp weather the roots again take hold, and the seeds are perfected after the cultivated plants are full grown, and the culture has ceased. This method of carrying away the plants, applies to many annual plants, which are generally of a vivacious nature.

20. The "Rest harrow," or the "Ononis" of botany, is sometimes met with on tillage land, where it forms a weed of a very troublesome nature. The plant belongs to the class and order "Diadelphia decandria" of Linneus, and the natural order " Papilionaceæ" of Jussieu.

Generic character.-Calyx : perianth five-leaved, almost the length of the corolla; segments linear, acuminate, slightly arched upwards, the lowest under the keel. Corolla: papilionaceous. Banner cordate, striated, depressed at the sides more than the other petals. Wings ovate, shorter by half than the banner. Keel acuminate, as long as, or longer than the wings. Stamina: filaments ten, connate in an entire cylinder. Antheræ simple. Pistil: germ oblong, villose ; style simple, rising; stigma blunt. Pericarp: legume rhomb-shaped, turgid, sub-villose, one-celled, two-valved, sessile. Seeds few, kindney-form.

Essential character. - Calyx five-parted, with linear segments; banner striated; legume turgid, sessile; filaments connate, without a fissure.

There are thirty-eight species of this genus of plants, of which only "one" is found in Britain, and is called the com- 
mon rest harrow, or Cammock, and by botanists the "Ononis arvensis." It is found on barren, sandy fields, and on way-sides, and flowers from June to September. The flowers are nearly sessile, and mostly solitary. Stem hairy. Branches at length spinous. Leaves generally simple, entire towards their base. Root perennial, woody, blackish. Stems rather erect, or procumbent, annual, round, woody, leafy, hairy, spinous when old. Leaves alternate, stalked, elliptically wedge-shaped, linear, roughish; the lower ones often ternate. Stipulas very large, ovate, embracing the stem, toothed. Flowers axillary, solitary, slightly stalked, elegantly rose-coloured. Seeds dotted with tubercles.

Some botanists make a distinction between the "Ononis arvensis" and the "Ononis spinosa" as being distinct species; but Mons. Villars does not distinguish them, alleging that the spines appear with the age of the plant, and growing stronger as the plant grows older. This observation removes much useless reasoning on minute differences.

The rest harrow has a strong creeping root, which spreads far in the ground. There is little danger from the seeds, and the safest way of eradicating the roots, is to pick them off the land by hand, after they have been well shaken by the harrows in dry weather. They may then be burned in a heap, or rotted with earths into a compost for top-dressing. This weed is not of difficult extirpation: a well-executed fallow will banish it for ever; and the appearance of it in modern agriculture shows that there is something wrong in the performance.

21. The common fern, or the "Pteris aquilina" of botanists, is sometimes found as a weed on corn lands. It belongs to the class and order "Cryptogamia filices" of Linneus, and the natural order "Filices" of Jussieu.

Generic character.-Fructification in an uninterrupted marginal line. Involucre from the margin of the frond turned in, uninterrupted, separating on the inner side.

The common fern or brake is the original type of the genus, and is the "Filix scemina" of old writers. The frond is in three deep divisions. Branches doubly pinnate. Leaf- 
lets crowded, lanceolate, acute; the upper ones confluent. The fronds are annual, originating from a perennial, creeping, scaly root, and rise, according to the soil, to the height of two to five feet. They are rigid and harsh, colour light green, and spread in a handsome, partly horizontal posture, being regularly compounded in an almost pectinate manner. The fructifications are rough, tomentose, rufescent; parallel lines run along the margin of the pinnules, which are rolled back very much, so as almost to cover the capsules when ripe.

The "Braken," or common fern, is a hardy perennial plant, tenacious of growth, and striking a long tap root into the ground, beneath the reach of the plough, which shoots up vigorously when the sun becomes powerful; it prevails largely and strongly on some deep, dry, hazel, loamy soils. The roots may be drawn after soaking rain, and the land must be very deeply ploughed; for, when the plant has been long established, it requires much pains and attention to get quit of it.

22. The "Horsetail," or the "Equisetum" of botany, is not unfrequently found as a weed on soft moist soils. It belongs to the class and order "Cryptogamia filices" of Linneus, and the natural order "Filices" of Jussieu.

Generic character.-Fructifications disposed into a long ovate, oblong spike, each orbiculate, gaping at the base, with several valves connected by a flat shield-shaped top.

The roots are perennial and creeping. They are leafless herbs, with a hollow streaked stem, either simple or branched, the branchlets usually disposed in whorls; it is jointed, and the joints are surrounded with a toothed sheath.

The "Corn horse tail," or the "Equisetum arvense," has the fruit-bearing scape naked, the barren scape leafy. The naked flowering stems appear early in the spring, and soon decay; they are the thickness of a large wheat straw, a hand's breadth or more in height, upright, yellowish, with from two to five joints, covered with membranous ribbed sheaths, divided at the top into numerous segments or teeth. It grows in corn fields of a damp nature, flowering in March, April, and May. The country people call it " horse-pipe and snakepipe." The presence of it is supposed to indicate subter- 
raneous flowing waters or springs. It is a troublesome weed, and difficult to extirpate. The produce of seeds being small, the chief attention must be directed to the destruction of the root, by the ploughings of the land being executed deeply with a narrow furrow, and with sharp irons on the plough, in order that the roots may not escape being cut.

23. The "Mouse-ear," or the "Cerastium" of botany, is often found infesting light soils. It has somewhat the habit of " chickweed," but is of a duller appearance.

It belongs to the class and order "Decandria Pentagynia" of Linneus, and the natural order "Caryophylleæ" of Jussieu.

Generic character. - Calyx: perianth five-leaved, leaflets ovate-lanceolate, acute, spreading, permanent. Corolla : petals five, bifid, obtuse, erect, expanding, length of the calyx. Stamina: filaments ten, filiform, shorter than the corolla, the alternate ones shorter; anthers roundish. Pistil: germ ovate; styles five, capillary erect, length of the stamens. Stigmas obtuse. Pericarp : capsule ovate, cylindric or globular, obtuse, unilocular, gaping with a five-toothed tip. Seeds very many, roundish.

Essential character.-Calyx five-leaved; petals bifid; capsule unilocular, gaping at the tip; orifice toothed.

The "Corn mouse-ear," or the "Cerastium arvense," has the root perennial, creeping. Stems four or five inches high, decumbent, forming thick tufts, pubescent. Leaves linearlanceolate, often densely pubescent, sometimes only ciliated at the base. Flowers large, white-leaflets of the calyx eggshaped, obtuse, scarious at the edges; petals heart-shaped, veined. Capsule cylindrical, straight, the length of the calyxorifice, with ten teeth.

This weed grows chiefly on gravelly and chalky soils. Nature has provided annual plants with an abundance of seeds, whereby to propagate their kind; and perennial plants have the property of propagation chiefly in the roots; and some plants are provided very largely with both qualities. In the eradication of perennial plants, where the roots are so very ready to catch hold of life, the most effectual method 
is to gather by hand, and carry the plants off the field, after being cut by the hoe, especially when the number is great, as a multitude of roots seldom fail in catching hold of the earth, and thus continue their existence, though the bearing of seeds has been prevented.

24. "Melilot," or the "Trefolium melilotus" of botany, is a very troublesome weed in some corn-growing districts. Legumes naked, racemed, two-seeded, wrinkled, acute. Stem erect. Root annual, strong, woody. Stem upright, grooved, yellowish green, two feet high or more, with spreading alternate branches.

The Melilot clovers form the first division of the genus, having the legumes naked, and many-seeded.

This plant grows wild in most parts of Europe, by waysides, in pastures and in corn fields. It is a very injurious corn weed; flowers in June, and the seeds ripen with the corn, and being ground with the grain the flour of wheat gets a strong unpleasant taste. But it is a good pasture plant; horses are very fond of it; cows, sheep and swine eat it, and bees delight to draw its nectary. It propagates very readily by the root and the seeds, and therefore a very careful fallowing of the land by the modes already recommended, becomes necessary for its extirpation.

25. The "Feverfew," or the "Pyrethrum" of botany, is a very common weed in corn fields. The plant belongs to the class and order "Syngenesia polygamia superflua" of Linneus, and the natural order "Corymbiferæ" of Jussieu.

Generic character.-Calyx hemispherical, imbricated; the scales close-pressed, rather acute, membranous at the edges. Corolla compound, radiated. Florets of the disk perfect, numerous, tubular, funnel-shaped, with five spreading segments; those of the radius more than twelve; female ligulate, elliptic, oblong, three-toothed. Stamina in the perfect florets; filaments five, capillary very short; anthers, united into a cylinder, hardly so long as the corolla. Pistil: germen in all the florets, obovate style, thread-shaped, longer than the stamens; stigmas two, divaricated, abrupt. Pericarp none, the calyx remaining unaltered. Seeds nearly alike in 
all the florets, oblong, quadrangular, each crowned with an erect, membranous, more or less lobed border. Receptacle naked, dotted, convex.

Essential character.-Receptacle naked. Seeds crowned with a membranous margin. Calyx hemispherical, imbricated with sharpish scales, bordered with a membrane.

The "Corn feverfew, or scentless Mayweed," the "Pyrethrum inodorum," has the leaves pinnate in many capillary segments. Stem branched, spreading; seed crown entire. Root tapering, annual. Branches somewhat corymbose, each terminated by a rather large flower, with long white rays, and a prominent yellow disk.

This weed grows mostly on gravelly soils, and flowers in autumn. Cutting up the plants by the hoe in drilled crops will prevent the seeds being perfected; and when perfect seeding does happen, the seeds must be very carefully separated from the grain by winnowing, and destroyed by burning.

26. The "Corn marigold," or the "Crysanthemum" of botany, is a very troublesome weed in some soils. The plant belongs to the class and order "Syngenesia polygamia superflua" of Linneus, and the natural order "Corymbiferæ" of Jussieu.

Generic character.-Calyx common, hemispherical, imbricated; interior scales larger by degrees, innermost membranous. Corolla compound, radiated. Florets of the ray female, and strap-shaped of the disk; hermaphrodite, funnelshaped, spreading the length of the calyx. Stamina five, capillary very short, anthers forming a hollow cylinder. Pistil: germ egg-shaped; style filiform, longer than the stamens; stigmas two, obtuse, revolute. Seeds one to each floret, oblong, not crowned with a marginal rim. Receptacle naked, dotted, convex.

Essential character. - Receptacle naked. Seed without a marginal ring. Calyx hemispherical, imbricated; scales dilated at the margin, membranous.

The "Corn marigold," or the " Chrysanthemum segetum," has the leaves embracing the stem glaucous, laciniated near the summit, toothed at the base. Root annual, spindle- 
shaped, small. Stem one or two feet high, branched, angular. Leaves oblong, variously toothed, or pinnatifid, lacinated, rarely entire. Flowers large, terminal; scales of the calyx with a broad membranous edge ; florets of the ray inversely heart-shaped, spreading. Seeds furrowed.

The plant is annual, and flowers from June to October. It has many provincial names : corn marigold, yellow or golden corn flower, yellow bottle, buddle, or the yellow bottle in Norfolk; golds, goulds, or gowls, in the midland counties; goulans, or goldins, in the north of England, and gules, gools, guils, or yellow gowans, in Scotland, from the golden colour of the flowers. The seeds are very plentifully produced, which vegetate whenever the land is cultivated, and may be very easily destroyed, like other annual seedling weeds, by early and complete fallowing, to bring the seeds forward, and then destroying the plant. The root being annual, the production of seeds has only to be guarded against.

27. The "Mint," or the "mentha" of botany, is a frequent weed on moist soils. It belongs to the class and order "Didynamia gymnospermia" of Linneus, and the natural order "Labiatæ" of Jussieu.

Generic character-Calyx : perianth inferior, of one leaf, tubular, erect, with five nearly equal teeth, permanent. Corolla, of one petal, erect, tubular, somewhat longer than the calyx ; limb in four deep, nearly equal segments, the uppermost only being rather the broadest, and cloven. Stamina : filaments four, awl-shaped, erect, distant, the two nearest ones longest; anthers roundish. Pistil: germen superior, fourcleft; style thread-shaped, erect, longer than the corolla; stigma in two divaricated divisions. Pericarp none, except the permanent straight calyx. Seeds four, small, generally abortive.

Essential character. - Calyx five-cleft, nearly equal. Corolla nearly equal, four-cleft, its broadest segment cloven. Stamens erect, distant.

The herbage and even the flowers of mint abound with resinous dots, the seat of an essential oil, on which the warm and aromatic qualities of the plants depend. The genus is 
one of the most natural possible, and well marked in habit and character. The herbage is generally more or less hairy.

The "Corn mint," or the "Mentha arvensis," has the flowers whorled. Leaves ovate. Stem much branched, diffuse. Calyx bell-shaped, clothed all over with horizontal hairs. The stems are much branched. Leaves inclining to elliptical, obtuse, pale, clothed with rather rigid prominent hairs. Flower stalks shortish, round, generally smooth, sometimes furnished with a few spreading or slightly deflıxed hairs. Calyx shorter, more bell-shaped and more broadly toothed than in any of the foregoing, and essentially characterised by being clothed all over with horizontally spreading hairs. Flowers reddish lilac, externally hairy.

This plant grows abundantly in corn fields where water stagnates in winter, especially on a sandy or gravelly soil. It is often a very troublesome weed, because of the widely creeping nature of the root, and its turgid fleshy shoots well calculated to retain life in a soil that fluctuates as to humidity. The roots being perennial, must be picked by hand, and carried from the field, each time when the land is ploughed, harrowed, and rolled. The roots are very tenacious of life, and must be carefully removed.

28. The "Blue bottle," or the "Centaurea" of botany, is sometimes found as a weed on corn fields. The plant belongs to the class and order "Syngenesia polygamia frustranea" of Linneus, and the natural order "Cinarocephalæ" of Jussieu.

Generic character.-Calyx common, imbricated, roundish scales variously terminated. Corolla: compound, floscular florets, differing in form; those of the disk hermaphrodite, numerous; those of the ray fewer, loose, larger, funnel-shaped, constantly abortive ; tube of the hermaphrodite florets filiform border, bellying, oblong, erect, terminated by five linear erect segments; tube of the abortive florets slender, gradually enlarging, recurved; border oblong, oblique, unequally divided. Stamens of the hermaphrodite florets : filaments five, capillary very short; anthers united into a hollow cylinder the length of the petal; of the abortive florets, none. Pistil 
of the former: germ small; style filiform, the length of the stamens; stigma very obtuse, projecting in a point, in many species bifid; of the latter, germ very small; style scarcely any; stigmas none. Seeds of the fertile florets solitary; down in most species feathered or capillary; receptacle bristly.

Essential character.-Receptacle bristly. Florets of the ray funnel-shaped, longer, abortive.

The "Corn centaury" has a stem one to two feet high, erect, much branched, somewhat woolly; calyxes serrate, leaves linear, quite entire, the lowest toothed. Root annual, fibrous, black. Leaves linear-lanceolate, acuminate, somewhat woolly; root leaves entire; lower stem leaves often pinnatifid or toothed; upper ones always entire. Flowers terminal, solitary, peduncled; florets of the disk purplish, regular; anthers black; florets of the ray funnel-shapedalways blue when wild; calyx egg-shaped; scales lanceolate. Seeds even-down, many-leaved, unequal, scabrous reddish. It flowers from June to September, and is easily extirpated by constant hoeing to prevent the perfecting of seeds; and the root being annual, there is no dread of propagation in that way. The oldest writers notice this plant, and it has been mentioned under various names.

29. The corn Chamomile, or stinking May weed, is a common plant on corn fields. It is the "Anthemis" of botany, and belongs to the class and order "Syngenesia polygamia Superflua" of Linneus, and the natural order "Corymbiferæ" of Jussieu.

Generic character.-Calyx common, hemispherical; scales linear, subequal. Corolla compound, radiate; corollules hermaphrodite, tubular, numerous in a convex disk; females more than five in the ray. Proper of the hermaphrodite funnel-shaped, five-toothed, erect; of the female ligulate, lanceolate, sometimes three-toothed. Stamina in the hermaphrodite: filaments five, capillary very short; antheræ cylindrical, tubular. Pistil in the hermaphrodites: germ oblong; style filiform, the length of the stamens; stigmas two, reflex; in the females germ oblong; style filiform, the length of the 
hermaprodites; stigmas two, revolute. Pericarp none; calyx unchanged. Seeds solitary, oblong, down-margined or none. Receptacle chaffy, convex or conical.

Essential character.-Receptaculum chaffy; down none; calyx hemispherical, nearly equal; floscules of the ray more than five.

The "Corn chamomile," or the "Anthemis arvensis," has the receptacles conic; chaffs bristle-shaped; seeds crownmargined; leaves thinly downed. Root biennial. Flowers in June and July. As this plant produces abundance of seeds, and the root is biennial or existing for two years, the extirpation of it requires a double care in gathering the roots by hand-picking of the fallowed lands, and to prevent the perfecting of the seed by cutting and pulling the plant during its growth.

30. The "Oat-like soft grass," or the "Holcus avenaceus" of botany, is a most troublesome weed on the best arable lands. The plant belongs to the class and order "Triandria digynia" of Linneus, and the natural order "Gramineæ" of Jussieu.

Generic character.-Calyx : glume of two valves; erect, beardless, ovate, containing two florets, one of them elevated on a stalk. Corolla of two valves, the lower or outer one largest, awned at the back in the least perfect floret; nectary a cloven membranous scale. Stamina : filaments three in each floret; capillary rather short; anthers long, linear, cloven at each end. Pistil: germen ovate; styles two, capillary, diverging; stigmas oblong, feathery. One floret has either no pistil, or only an imperfect one. Pericarp none, except the permanent glumes. Seed solitary, ovate, attached to the hardened corolla.

Essential character.-Calyx of two valves, two-flowered; one floret with an imperfect germen. Corolla of two valves; the outer one awned.

The species "Avenaceus" has the calyx glumes unequal, smooth; male floret lowest, with a bent awn. Root knotty, perennial. Stems a yard high. Leaves darkish green, rough, and rather harsh. Stipula short, abrupt, minutely toothed. 
Fanicle half-whorled, the branches consequently leaning one way. Flowers scariose, shining, not downy; anthers purple, pendulous. The male floret has the rudiments of a germen, and is always conspicuously awned; the other is but slightly elevated. When the land is rich, this plant grows luxuriantly, and acquires more joints and bulbs, and has been called "Holcus bulbosus," though only a variety of the plant now described.

This grass flowers in Jine and July, and forms a large part of the weeds which pass under the general denomination of "couch" and "quickens." No weed is more troublesome to the farmer on the better turnip soils, and on the more loamy clay fallows. The root is perennial, and composed of knobs or bulbs that are joined together at distances by intervening threads, and from each bulb shoots proceed, which circumstance renders the extirpation of the weed to be very difficult and tedious. Repeated ploughings and harrowings of the land become necessary, and then a very careful hand-picking of the roots of the plant after they have been well shaken into view by the action of the implements. On stiffish soils which hold the weed tightly in their texture, the sharp irons of the plough are very apt to cut the fibres into small pieces, which very much increase the difficulty of getting the land cleared of the weed. Accordingly on all lands whose degree of mellowness admits the action of a grubbing scarifier, the round tires of that implement tear out and pull to the surface the roots and fibres of the plant, without cutting or breaking them, and at the same time the ground is very superiorly pulverised. The roots are very tenacious of life, and no degree of arid exposure will destroy the vital principle. Decomposition in a heap along with other earthy matters, requires to be very minutely inspected at each turning over of the heap ; for some roots are very apt to escape on the outside of the compost, and which being carried to the land, will immediately grow, and multiply very fast. Even the burning of the roots in heaps on the field is not thoroughly safe : for the outside may escape ignition, and grow as before. The most effectual method is to carry the roots off the field 
at once, and to lay them in some waste corner, where they may be burned at leisure, or mixed and prepared in compost by a lengthened inspection.

31. The "Wheat grass," or the "Triticum" of botany, is a most pernicious weed. The plant belongs to the class and order "Triandria digynia" of Linneus, and the natural order "Gramineæ " of Jussieu.

Generic character.-Calyx, a common receptacle elongated into a spike; glume two-valved, sub-triflorous valves; ovate, bluntish, concave. Corolla two-valved, nearly equal, size of the calyx; exterior valve ventricose, blunt with a point; interior valve flat. Nectary two-leaved; leaflets acute, gibbous at the base. Stamina: filaments three, capillary; anthers oblong, forked. Pistil: germ turbinate; styles two, capillary reflexed; stigmas feathered. Pericarp none. Corolla fosters the seed, opens and drops it. Seed one, ovate oblong, blunt at both ends, convex on one side, grooved on the other.

Essential character.-Calyx two-valved, solitary, subtriflorous, or many-flowered, on a flexuose toothed rachis. Corolla blunt, with a point.

This genus comprehends all the varieties of the cultivated wheats, and the annual and permanent wheat grasses. The species we now mention as a weed, is the "Triticum repens" of botany, or the creeping wheat grass, and known by different names, as quick, quitch, twitch, couch, or dog's' grass, are evidently derived from quick, which signifies "living," in allusion to the very vivacious nature of the root. Calyx awlshaped, many-ribbed, five-flowered. Florets pointed. Leaves flat. Root creeping. Flowers in summer and autumn.

The roots have been dried and ground into meal, and made into bread in years of scarcity. The taste of the dried roots is sweet, and they are sold as food for horses; cows, sheep, and goats also eat them. Dogs eat the leaves to excite vomiting. The stems are two feet high, slender. Herbage green.

The long and deeply creeping roots are of all weeds the most difficult to extirpate. The root is regularly jointed, and from each joint the shoots proceed, which throw up the 
flowering stems. The recommendation given in the former weed, is now repeated, that the land be repeatedly grubbed and scarified in contrary and cross directions, in order to drag the weeds " entire" to the surface, and then to be carted off the field, in order to be burned or decomposed in an earthy mass. The roots are vivacious beyond any example, and require the most minute care that every twig of them, however small, be most carefully picked off the land, and removed.

The roots of the common grasses become weeds on arable lands, and farmers designate them all by the common name of "quickens" and "couch grass." Next to the two grass weeds now mentioned, the roots of the "Agrostis" family form the weed of the greatest abundance on damp loams, where they grow very vigorously. The roots are black in colour, fibrous and creeping, and throw out shoots from the joints, and are very tenacious of life. They are most generally called "bent grass."

32. The "Wild oat, or haver," or the "Avena fatua" of botany, is not uncommon as a weed on badly cultivated lands. Being perennial, and having a creeping root, it can only be reduced and banished by very careful fallowing of the land, and by picking off every root. And all root plants, or those that are propagated chiefly by the roots, are only to be eradicated by that process.

It may be laid down as a general rule, that in the case of annual weeds which produce a great profusion of seeds, the chief care is to be directed to prevent the perfecting of them, by cutting and pulling the plants when considerably grown in size, and even to remove them from the field altogether, as the roots are so very apt to catch hold of the earth, and grow again, and even perfect the seeds, so far' as to render them capable of germination. And in the case of perennial plants, which are propagated chiefly by the roots, the most diligent and minute care must be used, to pick by hand and carry from the field every inch of roots of any kind, after they have been separated from the earth by the repeated use of the implements that have been recommended. 
Sect. II.-Weeds on Meadow and Pasture Lands.

1. The "Cotton grass, harestail, or moss cups," or the "Eriophorum" of botany, grows in bogs or boggy meadows. The plant belongs to the class and order "Triandria monogynia" of Linneus, and the natural order "Cyperoideæ" of Jussieu.

Generic character.-Spike, or rather catkin, imbricated every way; scales ovate, oblong, flat, slightly inflexed, pointed, membranous, loose, separating the flowers. Corolla none. Stamina : filaments three, capillary; anthers erect, oblong. Pistil : germen superior, very small; style threadshaped, the length of the calyx scale; stigmas, three longer than the style, reflexed. Pericarp none. Seed triangular, pointed, surrounded at the base with numerous hairs longer than the spike.

Essential, character.-Glumes chaffy, imbricated every way. Corolla none. Seed one, invested with very long hairs.

The "Eriophorum vaginatum," the mountain or singlespiked cotton grass, has the culms sheathed, spike scariose. Root leaves obscurely three-cornered, sharp, streaked on two sides, convex on one side, flat on two sides. Flowers in April and May. Sheep are very fond of it. Ray calls it "Hare's tail rush ;" and in Westmoreland it is called "moss crops." It is a native of bogs or boggy pastures, in cold barren situations. The "Eriophorum augustifolium," or the "Narrow-leaved cotton grass," is very similar to this plant, and is often confounded with it. They grow in the same situations, and produce nearly similar flowers at the same time.

The presence of this plant as a weed is a certain indication that drainage has been neglected, and that it is of course necessary to be attended to and practised, in order to restore the meadow to the proper state for the growth of good herbage. Top-dressings with well-prepared composts must be applied at the same time. 
2. The "Hog weed, or cows' parsnip," or the "Heracleum" of botany, is a weed very often found on loamy damp meadows. The plant belongs to the class and order "Pentandria digynia" of Linneus, and the natural order "Umbelliferæ" of Jussieu.

Generic character.-General umbel of many rays, very large, partial, flat. General involucre of many leaves, deciduous, partial, halved on the outside; its leaflets from three to seven linear, lanceolate, the outer ones longest. Perianth scarcely discernible. Corolla universal, not uniform, radiated. Flowers for the most part all fertile, partial ; of the disk equal, of five, inflexed, hooked, emarginated petals; of the radius unequal, of five oblong, hooked petals ; the outer ones largest, and most deeply cloven. Stamina: filaments five, longer than the petals of the disk; anthers small. Pistil : germen inferior, nearly ovate; styles two, approximated, short; stigmas simple. Pericarp : fruit elliptical, compressed, emarginate, striated on each side in the middle. Seeds two, ovate, compressed, somewhat leafy at the edge.

Essential character.-Fruit elliptical, notched, compressed, striated, dilated in the margin. Flowers radiant. Petals notched, with an inflexed point. General involucre deciduous.

The "Heracleum sphondylium," or the "Common cows' parsnip," has the leaves pinnate or ternate, hairy, downy, and whitish beneath. Leaflets dilated, pinnatifid, cut, and serrated, heart-shaped at its base. The root is biennial, tap-shaped, whitish. Stem erect, branched, leafy, stout, hollow, furrowed and rough, about four feet high. Dr. Sibthorp found it in Greece, growing in wet places, as mentioned by Dioscorides. It is a native of most parts of Europe, and forms a genus of the most gigantic umbelliferous plants. It flowers from May to July. The leaves are a favourite food with rabbits and swine; kine, goats, and sheep also eat them; but horses are not fond of them.

This weed may be gradually weakened and ultimately destroyed by annually cutting it in its early growth. The tap 
roots may be split and destroyed by pushing salt down the incisions.

3. The "Wild cicely, or wild chervil, cow weed," or the "Chærophyllum" of botany, is a common weed in orchards and pastures. The plant belongs to the class and order "Pentandria digynia" of Linneus, and to the natural order "Umbelliferæ" of Jussieu.

Generic character.-Calyx, umbel universal, spreading, partial, nearly equal in the number of its rays. Involucre universal, generally none, partial, five-leaved, or more. Leaflets lanceolate, concave, reflexed, about the length of the partial umbel. Perianth proper, scarcely discernible. Corolla universal, nearly uniform. Florets of the disk often abortive. Proper petals five, inflexed, heart-shaped, with an inflexed point, flattish, outer ones a little larger. Stamina: filaments five, simple, the length of the little umbel; anthers roundish. Pistil: germen inferior; styles two, reflexed; stigmas obtuse. Pericarp none. Fruit oblong, acuminate, even, divisible into two. Seeds two, oblong, attenuated upwards, convex on one side, flat on the other.

Essential character.-Involucre reflexed, concave. Petals inflexed, heart-shaped. Fruit oblong, even.

The "Chærophyllum sylvestre," or the "Smooth cow parsley," has the stem striated, slightly swelling below the joints. Root perennial, spindle-shaped, slightly milky, but little branched. Stem about three feet high, erect, branched, leafy, round, downy towards the bottom, almost always void of pubescence above. Leaves triply pinnated, deeply cut, rough at the edge; petioles short, dilated, ribbed. Flowers whitish; umbels erect, terminal. Leaves of the partial involucre egg-shaped, membranous, fringed with thick-set white hairs; petals more or less emarginate, rarely entire. Fruit oblong, somewhat elliptical, roundish, very slightly striated, quite smooth. Flowers in April and May, and grows very common in meadows and pastures in most parts of Europe, and always indicates a luxuriant, soil. Grazing animals are indifferently fond of eating it. It flowers and ripens the seeds before any of the proper grasses. 
This weed may be weakened and destroyed by the same means as recommended in the case of the last-mentioned plant.

4. The "Rush" plant, or the "Juncus" of botany, are not unfrequently found as weeds in meadows and pastures. The plant belongs to the class and order "Hexandria monogynia" of Linneus, and the natural order "Junci or Juncex" of Jussieu.

Generic character.-Perianth, of six oblong, pointed, permanent leaves, inferior. Corolla none. Stamina: filaments six (in the common rush, only three); capillary very short; anthers oblong; erect, the length of the perianth. Pistil: germen superior, pointed, triangular; style short, threadshaped; stigmas three, long, thread-shaped, downy, inflexed. Pericarp: capsule invested with the calyx, tringular, of three more or less completely divided cells, with three valves, the partitions from their centre. Seeds various in number, rarely solitary, roundish.

Essential character. - Calyx of six leaves, permanent. Corolla none. Capsule superior, of three valves, with one or three cells. Seeds several; stigmas three.

The "Common rush" or "Juncus conglomeratus," is triandrous, and belongs to the first section, or plants that have a leafless stem, the culm being naked and stiff, and the head lateral. Root perennial, horizontal, close, covered with ovate scales; fibres filiform, very long. Culms from one to two feet in height, upright, round, smooth; sheaths at the base, striated, blunt, leafless, awned, the uppermost three times as long as the rest. Root leaves few, very like the culms. Head of flowers roundish, solitary, seldom two together, from the fissure of the culm bursting out below the top.

The rush plants grow on soils varying from the poorest gravelly clays, to the best and deepest loams, and always indicating an excess of moisture. Draining of the land is the first step in remedy, and to be assisted by top-dressings of ashes, and other earthy matters. The roots may also be dug. up by the spade, and reversed in the pit, when they generally die, and give place to better herbage. 
5. "Tansey," or the "Tanacetum" of botany, is sometimes found as a weed on very good meadows. The plant belongs to the class and order "Syngenesia polygamia superflua" of Linneus, and the natural order "Corymbiferæ" of Jussieu.

Generic character.-Calyx common, hemispherical, imbricate; scales acute, compact. Corolla compound, tubular, convex. Corollets hermaphrodite, numerous, tubular in the disk ; females, some in the ray. Proper of the hermaphrodite : funnel-form, with a five-cleft reflexed border; female, trifid, more deeply divided inwardly. Stamina in the hermaphrodites : filaments five, capillary very short; anthers cylindric, tubular. Pistil in the hermaphrodites: germ oblong, small ; style filiform, length of the stamens; stigma bifid, revolute. In the females, germ oblong; style simple; stigmas two, reflexed. Pericarp none. Calyx unchanged. Seeds solitary, oblong. Down slightly margined. Receptacle naked.

Essential character.-Calyx imbricate, hemispherical. Corolla : rays obsolete, trifid (sometimes none, and all the florets hermaphrodite). Down submarginate. Receptacle naked.

The "Common tansey," or the "Tanacetum vulgare," has the leaves bipinnatifid, sharply serrated, naked. The root is fibrous and creeping, and spreads to a great distance. It is bitter, and has a strong aromatic smell. Stems upright, from two to four feet high. Flowers from June to August, and compose a large, flattish, terminal, golden corymbus.

This weed is a native of most parts of Europe, and grows mostly on the banks of rivers, and low places that are moderately swampy. As it propagates chiefly by the roots, they must be dug up by the spade, or the weeding "spit or tongs."

6. The "Yellow rattle," or the "Rhinanthus" of botany, is a very common weed on moist meadows. The plant belongs to the class and order "Didynamia angiospermia" of Linneus, and the natural order "Pediculares" of Jussieu.

Generic character.-Calyx : perianth inferior, of one leaf, roundish, inflated, compressed, four-cleft, permanent. Corolla 
of one petal, ringent tube, rather cylindrical, the length of the calyx; limb gaping, compressed at the base; upper lip helmet-shaped, compressed, emarginate, narrower; lower, spreading, flat, trifid half-way down, obtuse, the middle segment broader. Stamina: filaments four, the length of the upper lip, the two shorter ones concealed under it; anthers incumbent, cloven on one side, hairy. Pistil: germen superior, ovate, compressed; style thread-shaped, longer than the stamens, but standing between them; stigma obtuse, inflexed. Pericarp: capsule obtuse, erect, compressed, of two cells, and two valves, gaping at the margins: partition contrary. Seeds numerous, compressed.

Essential character.-Calyx inflated, compressed, fourtoothed. Upper lip of the corolla compressed. Capsule of two cells, blunt, compressed. Seeds imbricated, flat.

The "Cock's comb yellow rattle," or the "Rhinanthus crista galli," has the root annual, small, with small fibres. The whole plant is smooth. Stem a foot or more in height, fourcornered, mostly stained with dark purple. Leaves in pairs, spike, terminating leafy. Bractes like the leaves, only broader at the base, and more deeply cut in. Flowers not always strictly opposite, on short peduncles. Calyx remarkably large, inflated, of a pale greenish yellow colour, with strong ribs, and a network of veins. Corolla twice as long as the calyx; yellow, except the tube, which is white, and the anterior edge of the upper lip, which is dirty blue; anthers awnless, but very hairy; germs smooth, surrounded at the base by membranaceous nectary. Capsule rounded, emarginate at top, two-celled, two-valved. Seeds from eight to twelve in each cell, kidney-shaped. It flowers early in June.

This plant gets the name of "Yellow rattle," from the rattling of the ripe seeds in the capsule; and for the same reason it is called "rattle boxes" in Ireland. It is sometimes called "penny-grass," and in Yorkshire "hen-penny," from the shape and size of the seed vessel, like a silver penny. The name of "cock's comb" is derived from the appearance of the upper leaves or bractes which accompany the flowers. Having no quality to recommend it for grazing, it should be 
carefully extirpated, by the meadow being grazed for three or four years to prevent the seeding, and by cutting with the scythe any plants that may escape the bite of the grazing animals, and shoot up the seed stems. The root is annual, or at most biennial.

7. "Yarrow and sneeze wort," or the "Achilleæ" of botany, are common plants on some dry warm pastures. The plant belongs to the class and order "Syngenesia polygamia superflua," of Linneus, and the natural order "Corymbiferæ" of Jussieu.

Generic character.-Calyx common ovate, imbricate; scales ovate, acute, converging. Corolla compound, radiate; corollets hermaphrodite, tubular in the disk. Females ligulate, five to ten in the ray. Proper of the hermaphrodite, funnel-shaped, five-cleft, spreading. Female obcordate, spreading, trifid; the middle cleft less than the others. Stamina in the hermaphrodites: filaments five, capillary very short; antheræ cylindrical, tubular. Pistil in the hermaphrodites: germ small; style filiform, the length of the stamens ; stigma obtuse, emarginate. In the females germ small; style filiform, the same length as in the others; stigmas two, obtuse, reflex. Pericarp none. Calyx scarcely changed; receptacle filiform, elongate as the disk of the seeds; ovate twice the length of the calyx. Seeds solitary, ovate, furnished with flocks; but having no down. Receptacle chaffy, elevated-chaffs, lanceolate the length of the florets.

Essential character.-Calyx ovate, imbricate; florets of the ray about four ; down none. Receptacle chaffy.

Most of the plants of this genus are hardy, herbaceous, fibrous-rooted perennials, with the flowers commonly in corymbs at the ends of the stalk and branches; the ray in some yellow, in others white, in a few purple; the leaves in many of the species are pinnate, bipinnate, or superdecompound; in a few they are simple. Only two species are natives of Britain, the "Achillea millefolium," the common yarrow, and the "Achillea Ptarmica," or sneeze wort. The former has the leaves bipinnate, naked; divisions linear, toothed. Stems furrowed towards the top. It flowers from 
June to September, and grows abundantly in pastures and on road-sides. The medicinal qualities are yet allowed, and probably the plant may be regarded rather useful as a medicine than noxious as food. The root being perennial and creeping, the only method of extirpation is to raise the roots by hand-labour with the three-pronged fork.

The "Achillea ptarmica" flowers in July and August, and a double variety of it forms the "bachelors' buttons." It grows very commonly in meadows, by the sides of ditches, in moist woods, and shady places. To eradicate it, the roots must be raised with forks by hand-labour.

8. The "Pilewort," or the "Ficaria" of botany, abounds as a weed in shady moist grounds. It is easily known by its tuberous roots. Leaves cordate, shining. Stems many, leafy, red at bottom, four inches long. Flowers upright. Seeds sub-ovate.

The "pilewort" often occupies much room, and chokes other plants which grow near it, and not being eaten by cattle, it should be extirpated. Coal and wood ashes are very effectual in destroying it. The general effect of top-dressings is to kill succulent plants, and encourage the fibrous and gramineous.

9. The "Cud weed," or the "Gnaphalium" of botany, is sometimes seen on pastures where the sown grasses have missed. The plant belongs to the class and order "Syngenesia polygamia superflua" of Linneus, and the natural order "Corymbiferæ" of Jussieu.

Generic character.-Common calyx imbricated, rounded; scales numerous, the marginal ones rounded; scariose coloured. Corolla : compound-florets of the disk tubular, funnel-shaped, in five equal reflexed marginal segments ; some female ones without a corolla, are often intermixed towards the margin. Stamina (in the perfect florets): filaments five, very short capillary; anthers forming a cylinder. Pistil (in the same florets): germen ovate; style thread-shaped, the length of the stamens; stigma cloven. In the female ones the same. Pericarp none, except the permanent shining calyx. Seeds in both kinds of florets alike, solitary, oblong, small, crowned with capillary or feathery down. Receptacle naked. 
Essential character.-Receptacle naked. Down capillary or feathery. Calyx imbricated, its inner scales rounded, scariose coloured.

This weed is not very abundant, and is extirpated without very much difficulty by cutting the stems below ground with a narrow spade that is made for the purpose of cutting large roots.

10. The "Marsh marygold," or the "Caltha palustris" of botany, often occupies much space on damp meadows. The plant belongs to the class and order "Polyandria polygynia" of Linneus, and the natural order "Ranunculaceæ" of Jussieu.

Generic character.-Calyx none. Corolla: petals five, ovate, flat, spreading, deciduous, large. Stamina : filaments numerous, filiform shorter than the corolla; antheræ compressed, obtuse, erect. Pistil: germ superior, five to ten, oblong, compressed, erect; styles none; stigmas simple. Pericarp: capsules as many, short, acuminate, spreading, one-celled, two-keeled, gaping in the superior suture. Seeds many, ovate or ovate-oblong, smooth, affixed to a superior suture in a double row.

Essential character.-Calyx none; petals five; nectary none; capsule several, many-seeded.

There is only one species of the genus, or the "Caltha palustris," called marsh marygold, or meadow-bowts, or water blobs. The root is perennial. Stems several, almost upright; about a foot high, hollow, nearly round, smooth, branched, purple at bottom. Radical leaves on long petioles, cordate; reniform, smooth, shining, and notched or crenated; sometimes scalloped, sometimes entire. Stem-leaves nearly sessile, more pointed at top, and sharply crenated. Stipules brown, membranous, and withering. Branches dichotomous. Peduncles one-flowered, upright, grooved. Seeds beautiful, at bottom of an olive, and at top of a reddish, colour. It flowers in March and April and so early as February. The plant is disagreeable to grazing animals; and should be rooted out by the means recommended for the last weed.

11. The "Nettle," or the "Urtica" of botany, often grows 
in tufts on good pasture grounds. The plant belongs to the class and order "Monoecia tetrandria" of Linneus, and the natural order "Urticæ" of Jussieu.

Generic character. - Male calyx: perianth of four roundish, concave, obtuse leaves. Corolla: petals none; nectary; the rudiments of a germen central, small, pitchershaped, undivided, tapering at the base. Stamina : filaments four, awl-shaped, spreading, the length of the calyx, and opposite to its leaves; anthers of two globular. cells. Female generally on the same plant. Calyx: perianth of two, ovate, concave, erect, permanent valves. Corolla none. Pistil : germen superior, ovate; style none; stigma downy. Pericarp none, except the closed calyx. Seed solitary, ovate, compressed, blunt-edged, polished.

Essential character.-Male calyx of four leaves. Corolla none. Rudiment of a germen cup-shaped.

Female calyx of two leaves. Corolla none. Seed one, superior, polished.

The "Common stinging nettle," or the "Urtica dioica," has the leaves opposite, heart-shaped, sharply serrated. Stipulas ovate, distinct, spreading. Clusters much branched, in pairs; longer than the foot stalks, mostly dioicous. The root is perennial, and extensively creeping. The stems are two to three feet in height. Every part is armed with stings.

Where nettles grow in pastures, the roots must be very carefully raised by spade or fork and burned. The weed is not difficult of eradication, and the presence of it shows the most careless neglect.

12. The "Dandelion," or the "Leontodon" of botany, is a disagreeable plant, though common on good lands in most districts. The plant belongs to the class and order "Syngenesia polygamia $\mathbb{E q u a l i s " ~ o f ~ L i n n e u s , ~ a n d ~ t h e ~ n a t u r a l ~ o r d e r ~}$ "Cichoraceæ" of Jussieu.

Generic character.-Common calyx imbricated, oblong; its interior scales linear, parallel, equal; outer scales fewer in number, often reflected at the base. Corolla compound, imbricated, uniform; the florets hermaphrodite, numerous, equal, each of one petal, ligulate, linear, abrupt, with five 
teeth. Stamina : filaments five, capillary very short; anthers united into a cylindrical tube. Pistil : germen nearly ovate; style thread-shaped, as long as the florets; stigmas two, revolute. Pericarp none, except the oblong, straight, at length reflexed, calyx. Seeds solitary, oblong, rough ; down capillary, stipitate. Receptacle naked, dotted.

Essential character.-Receptacle naked; calyx dotted, imbricated with rather lax scales. Down stalked, hairy.

The "Common dandelion," or the "Leontodon taraxacum," has the outer scales of the calyx reflexed. Leaves liontoothed, smooth. Flowers from April to July. The root is deep and perennial, and very branching. Leaves radical, runcinate, toothed, of a bright green colour, smooth. Flower stalks simple, longer than the leaves, hollow, brittle, milky, and single-flowered. Flower terminal, large, golden-coloured, closing in the evening; styles hairy; seeds obovate, furrowed, bearing on a long footstalk a tuft of simple radiated down. The whole herb is milky and bitter.

The dandelion is a troublesome though handsome weed. Goats eat it; swine devour it greedily; sheep and kine are not fond of it; horses refuse it; small birds are fond of the seeds. The young leaves are used in salads, and the plant is diuretic in quality. Hence it may be useful in pastures. It is coarse, but good in hay with grasses. The eradication may be effected as in the case of the last two mentioned weeds.

13. "Garlick," or the "Allium" of botany, is frequently found as a weed on very good pastures. The plant belongs to the class and order "Hexandria monogynia" of Linneus, and the natural order "Asphodeleæ" of Jussieu.

Generic character.-Calyx: spathe common, roundish, withering, many-flowered. Corolla: petals six, oblong. Stamina: filaments six, subulate, often the length of the corolla; antheræ oblong, upright. Pistil: germ superior, short, bluntly three-cornered, the corners marked with a line; style simple; stigmas short. Pericarp: capsule very short, broad, three-lobed, three-celled, three-valved. Seeds few, roundish. 
E'ssential character.-Corolla six-parted, spreading; spathe many-flowered, umbel heaped; capsule superior.

The "Great round-headed common garlic," or the "Allium ampeloprasum," flowers in July and August. Umbel globose; stamens three-cusped; petals with rough keel. Stem one foot or more in height, having leaves at the bottom, glaucous and succulent; the spathe is conical, one-leaved, and deciduous. It flowers in a close ball or peduncles, which are about one inch in length. It is perennial, and communicates its flavour to the milk and butter of cows that eat it. It is not "singly" liked by any animal, but is eaten in mixture with other grasses.

The most effectual means of eradication, is by raising the roots by a spade or fork, and destroying them.

14. "Lousewort," or the "Pedicularis" of botany, is a very frequent weed on moist meadows and pastures. The plant is very beautiful, and belongs to the class and order "Didynamia angiospermia" of Linneus, and the natural order "Pediculares" of Jussieu.

Generic characters.-Calyx : perianth one-leafed, roundish, ventricose, with a five-cleft equal mouth, permanent. Corolla one-petalled, ringent; tube oblong, gibbous; upper lip galeate, erect, compressed, emarginate, narrower; lower spreading, flat, half three-cleft, blunt; middle segment narrower. Stamina : filaments four, the length of the upper lip, under which they lie concealed; two shorter; antheræ incumbent, roundish, compressed. Pistil: germen roundish; style filiform, in the same situation with the stamens, but longer; stigma blunt, bent in. Pericarp : capsule roundish, mucronate, oblique, two-celled, opening at top; partition contrary. Seeds several, ovate, angular; receptacle sublobular, in the base of the capsule.

Essential character.-Calyx five-cleft; capsule two-celled, mucronate, oblique; seeds coated.

The "Common or heath lousewort," or the "Red rattle," the "Pedicularis sylvatica," has the stem branched, calyxes oblong, angular, even ; lip of the corollas cordate. Stem very short; branches from the root, long, spreading close to the 
ground. Leaves simply pinnate, with roundish acutely serrated spinas. Floral leaves deeply divided; segments toothed. Leaves and flowers crowded. Flowers in June, and is found in wet pastures, heaths, and woods, in most parts of Europe.

This weed may be got rid of by removing the wetness of the land by draining, and by top-dressing the surface with compost manures.

15. The "Self-heal," or the "Prunella" of botany, is a very abundant weed on poor clay soils, in pastures of two and three years. The plant belongs to the class and order "Didynamia Gymospermia" of Linneus, and the natural order "Labiatæ" of Jussieu.

Generic characters.-Calyx : perianth one-leafed, twolipped, shorter in the throat, permanent; upper lip flat, wider, truncate, very slightly three-toothed; lower lip erect, narrower, acute, semibifid. Corolla: one-petalled, ringent; tube short, cylindrical; throat oblong; upper lip concave, entire, nodding; lower lip reflex, trifid, blunt; middle segment wider, emarginate, serrate. Stamina: filaments four, awl-shaped, forked at top, two of them a little longer than the others; anthers simple, inserted into the filaments below the top as it were on another branch. Pistil : germen four-parted; style filiform, with the stamens bending to the upper lip; stigma bifid. Pericarp none; calyx closed, containing the seeds. Seeds four, subovate.

Essential character.-Filaments forked at the apex, with an anther on one of the forks; stigma bifid.

The "common self-heal," or the "Prunella vulgaris," has the root perennial, and very fibrous. The whole plant is thinly set with hairs, the hairs upright and white. Stem from six to twelve inches in height, upright, commonly branching from the very bottom, hairy, purplish, especially towards the top. Branches in pairs at each joint, brachiate, ascending. Leaves bluntish, hairy, obsoletely toothed or repand; petioles channelled above, and hairy along the edges. The flower is violet-coloured, with a white tube, and easily falls. Seeds smooth, brown, terminated by a 
white point. Flowers from June to August, and found in meadows and pastures in most parts of Europe. The size varies much: in open, exposed situations it is short and trailing; but where drawn up among high grass, and especially in woods, it is upright and a foot high.

In permanent meadows this plant may be banished by top-dressings, and in pastures of a few years' duration it will yield to the effects of a careful fallowing of the land.

16. The "Wild-campion," or the "Lychnis" of botany, is a weed of very frequent abundance on pastures formed from ploughed lands. The plant belongs to the class and order "Decandria Pentagynia" of Linneus, and the natüral order "Caryophylleæ" of Jussieu.

Generic characters.-Calyx : perianth one-leafed, oblong, membranaceous, five-toothed, permanent. Corolla: petals five, claws the length of the calyx, flat, margined, border often cloven, flat. Stamina: filaments ten, longer than the calyx, alternately shorter, each of these fixed to a claw of each petal; antheræ incumbent. Pistil: germen subovate; styles five, awl-shaped, longer than the stamens; stigmas reflex against the sun, pubescent. Pericarp: capsule approaching to an ovate form, covered; one, three, or fivecelled, five-valved. Seeds very many, roundish.

Essential character.-Calyx one-leaved, oblong, even. Petals five, with claws and a sub-bifid border. Capsule five-celled (in most one-celled).

The "wild red campion," or the "rose-coloured Lychnis," has the flowers dioicous; capsules one-celled, roundish. Root perennial, the thickness of the little finger; white, of a slightly acrid and bitter taste, furnished with numerous fibres. Stalks several, upright, from one to three feet high, round, hirsute, jointed, purple; the joints swelled; the uppermost branches forked.

The "common campions" are red and white in colour. They are not common on permanent meadows, and they are most effectually banished from ploughed pastures, by a careful fallowing of the land.

17. "Dyer's broom," or the "Genista" of botany, is a 
very abundant weed on strong and moist pastures. It belongs to the class and order "Diadelphia Decandria" of Linneus, and the natural order "Leguminosæ" of Jussieu.

Generic characters.-Calyx : perianth inferior, of one leaf, small, tubular, two-lipped; the upper lip with two teeth, more deeply divided; lower, with three nearly equal teeth. Corolla papilionaceous; standard oblong, remote from the keel, entirely reflexed; wings oblong, lax, shorter than the other petals; keel straight, emarginate, longer than the standard. Stamina: filaments ten, all united, emerging from the keel; anthers simple. Pistil: germen oblong, enveloped by the common filament; style simple, directed upwards ; stigma acute, involute. Pericarp: legume roundish or oblong, turgid; of one cell, and two valves. Seeds several, mostly kidney-shaped, with a smooth elevated border round the scar.

Essential character.-Calyx two-lipped; the upper lip with two teeth; lower with three. Standard oblong, bent backwards from the rest of the flower.

This "genus of plants are mostly European; shrubby, with tough angular stems and branches, either ternate or simple leaves, and yellow flowers. The species are twenty-five in number, partly unarmed, and partly furnished with spines. The spinous ones have all simple leaves. Three "Genistæ" are natives of Britain.

The "Genista tinctoria," or the "Dyer's green weed," is the most common in England, and grows mostly on dry pastures. It is refused by no grazing animals but sheep, and it is supposed to give a bitter flavour to the milk of cows that feed upon it. It is rooted out by raising the plants by means of spades and forks.

18. The "Orchis" plant of several kinds, is common on most meadows. The plant belongs to the class and order "Gynandria monandria" of Linneus, and the natural order "Orchideæ" of Jussieu.

Generic character.-Calyx : perianth superior, of three spreading leaves, the uppermost vaulted. Corolla: petals two, often approximated, or attached to the upper leaf of 
the calyx. Nectary, a spreading lip, with a tubular spur behind. Stamina : anther large, oblong, erect, attached in a parallel manner to the summit of the style; of two cells, opening in front; the masses of pollen club-shaped, attaching themselves each by its taper base to one or two glands by the stigma, in one and the same pouch; style columnar, short; stigma below the anther, convex, oblique. Pericarp : capsule oblong, with three ribs; of one cell, and three valves, splitting by three lateral fissures. Seeds numerous, minute, each with a chaffy tunic.

Essential character.-Upper leaf of the calyx vaulted. Lip of the nectary, with a posterior spur. Anther terminal, parallel. Masses of pollen stalked, their bases approximated within a simple pouch.

The "Orchis" is a very extensive genus, containing fiftytwo species, in five divisions. The most common in Britain, in damp shady meadows, are the "Orchis pyramidalis," and the "Orchis maculata," or the spotted "Orchis." The former has the bulbs undivided; lip of the nectary two-horned, trifid, equal, quite entire; horn long. Petals sub-lanceolate. Bulbs ovate. Stem, from eight to fifteen inches high, round, or slightly angular, smooth and firm, almost covered with leaves. Flowers numerous, about eighty, crowded in a short blunt cone, forming a most elegant termination to the stem; deep flesh colour, or pale purple. The leaves are linear lanceolate, and of a silky glossiness, and the bulging protuberances on the lip of the nectary give a very distinguishing character to this species. Flowers in June and July.

The "Orchis maculata," or the spotted "Orchis," has the bulbs pulmate, spreading; horn of the nectary shorter than the germen; lip flat; dorsal petals erect. Bulbs palmated, compressed, with the segments much divaricated. Stem solid, from eight to eighteen inches high; the lower part round, the upper somewhat angular. Lower leaves embracing the stem; lowest constantly short, broad and blunt; the next considerably longer, bluntly lanceolate, above these, more acutely lanceolate; upper ones very narrow, and apparently sessile, but the margins are decurrent, whence the angular 
appearance of the stem; beneath they are silvery green, with parallel green nerves; above, pale green, often partially covered with the same silvery skin, marked with numerous reddish brown spots, mostly oval and transverse, but sometimes irregular. Flowers numerous, about forty, in a loose conical spike. Corolla, usually pale purple ; anthers green. It flowers in June and July.

These plants grow chiefly in woods, and on damp meadows. On dry pastures the size is reduced to the one-half, and has fewer flowers. All grazing animals refuse to eat them. The roots being strictly perennial, and the plant being seldom propagated by seed, the eradication consists in raising the roots by means of small spades, and then destroying them. The stalks and leaves are juicy, and retard the process of haymaking.

19. The "Eye-bright," or the "Euphrasia" of botany, grows very abundantly on dry pastures. The plant belongs to the class "Didynamia angiospermia" of Linneus, and the natural order " Pediculares" of Jussieu.

Generic character.-Calyx : perianth of one leaf, inferior, cylindrical, four-cleft, equal, permanent. Corolla of one petal, ringent; tube as long as the calyx ; upper lip concave, notched; lower spreading, deeply three-lobed, its lobes, equal and obtuse, notched. Stamina: fllaments four, threadshaped, situated close under the upper lip; anthers of two lobes, the lobes unequally spinous at their lower extremities. Pistil: germen superior, ovate; style thread-shaped, agreeing in form and situation with the stamens; stigma obtuse, undivided. Pericarp : capsule ovate, oblong, compressed, of two cells, and two valves; the partition contrary to the valves. Seeds numerous, minute, roundish, longitudinally striated.

Essential character. - Calyx cylindrical, four-toothed, equal; upper lip of the corolla cloven; lower three-lobed, the lobes cloven. Anthers bearded with unequal spines. Capsule ovate, oblong. Seeds striated.

Two species abound in British pastures: the "Common eye-bright," or the "Euphrasia officinalis," and the "Red eye-bright," or the "Euphrasia odontites." The former has 
the leaves ovate, marked with lines, sharply toothed. Root annual. Stem from two to four inches high or more, upright, round, hoary, purple, for the most part branched, in opposite pairs. Leaves opposite, sessile, obtuse, convex above, concave beneath, finely ciliate about the edge, slightly hirsute on each side, above somewhat glossy. Flowers from the axils of the leaves, on short peduncles, opposite, forming a spike or raceme at the tops of the branches and stem. It differs much in size and colour of the corolla, which varies to quite white and yellow; it is more or less branching, and sometimes wholly unbranched. It seems to have been unnoticed by the ancients, and there appears to be no foundation for the old notion of its being useful in disorders of the eyes.

This plant flowers from July to September, and grows very common on heaths and other dry pastures, especially on a chalky soil. It sheds a fair quantity of ready growing seeds, and, the root being annual, the prevention of the seeds being perfected offers the only way of eradicating the plant. Topdressings with well-prepared composts have always the effect of banishing weeds, and of bringing forward the useful grasses. Close grazing of the land with sheep, has the same effect; and the folding of the animals regularly over the field will produce a very good herbage, which will last for several years. This is a very cheap and effectual mode of restoring neglected and worn-out pastures, where, for special reasons, the ploughing up of the sward is absolutely forbidden.

20. "Sedge grasses," or the "Carex" of botany, are very common on old, sour, moist, clayey lands, of the meadow and pasture kind, that are undrained and unimproved. It belongs to the class and order "Monœcia triandria" of Linneus, and the natural order "Cyperoideæ" of Jussieu.

Generic character.-Flowers disposed in one or more oblong, imbricated catkins; the male and female in some species are the same, in others on distinct catkins. Male: calyx glume, one-valved, one-flowered, lanceolate-acute, concave, permanent. Corolla none. Stamina: filaments three, bristleshaped, erect, longer than the calyx; anthers erect, long, linear. Female: calyx as in the male. Corolla: petals 
none. Nectary inflated, oblong, egg-shaped, contracted upwards, opening at the tip, sometimes with two teeth, permanent. Pistil: germen three-sided, within the nectary; style simple; stigmas either three or two, awl-shaped, incurved, long, acuminate, pubescent. Pericarp none, except the enlarged nectary, which protects the seed. Seeds single, acutely egg-shaped, most frequently three-sided, one angle often less than the other.

Essential character. - Seed inclosed in the permanent nectary.

These plants are very nearly allied to the grasses, and agree with them in their general appearance, leaves and placentation. They are, however, of a much harsher texture, and the stem is not hollow, but filled with a spongy substance, and it is frequently three-cornered. The difference in the fructification is very considerable; and the stem has no joints, which is the never-failing distinction of a true grass plant. The "sedge grasses" are perennial, and flower from April to August. They grow in wet, swampy grounds, in bogs, fens, and marshes, or by the sides of ditches and rivers, or in moist woods ; some few, however, affect heaths and hilly pastures. They are eaten by no grazing animal, and seem produced by nature from a principle in her economy, that a bad plant is better than none. Upon getting quit of the superfluous moisture in the land, and by top-dressing the surface, the plants will commonly give way to a finer and more valuable herbage.

The "Sedge grass," though generally reckoned a weed, is not without its use. The herbage is very coarse and harsh, and relished by no animal. The roots give stability to bogs; the plants are used for covering hovels and ricks, for lighting fires and heating ovens, and for tying young hop plants to the poles. In Lapland, the inhabitants comb and dress some species of sedge, as we do flax, and use it as a defence against the rigours of the climate.

21. "Black knap weed," or the "Centaurea " of botany, is a common and abundant weed in some moist and cold meadows and pastures. The plant belongs to the class and 
order "Syngenesia polygamia frustranea" of Linneus, and the natural order "Cinarocephalæ" of Jussieu.

Generic character.-Calyx common, imbricated, roundish; scales variously terminated. Corolla compound, floscular; florets differing in form; those of the disk hermaphrodite, numerous ; those of the ray fewer, loose, larger, funnelshaped, constantly abortive; tube of the hermaphrodite florets filiform ; border bellying, oblong, erect, terminated by five linear erect segments; tube of the abortive florets slender, gradually enlarging, recurved; border oblong, oblique, unequally divided. Stamina of the hermaphrodite florets : filaments five, capillary very short; anthers united into a hollow cylinder the length of the petal; of the abortive florets none. Pistil of the former : germ small; style filiform; the length of the stamens; stigma very obtuse, projecting in a point; in many species bifid; of the latter germ very small; style scarcely any; stigmas none. Seeds of the fertile florets solitary; down in most species feathered or capillary; receptacle bristly.

Essential character.-Receptacle bristly. Florets of the ray funnel-shaped, longer, abortive.

The common pasture weed is the species "Centaurea nigra" of botany, which has the calyxes ciliate, with the little scale ovate ; cilias, capillary, erect; leaves lyrate, angular ; flowers floscular. Stem from two to three feet in height, angular, scored, slightly downy, often tinged with purple. It has many provincial names, as knap-weed, knop-weed, knob-weed, horse-knops, all from "knob or nob," a head; also " hardheads, hard-irons ;" and in Scotland it is called "horse-knot." It is a very harsh, stubborn plant, seldom touched by cattle, either green or in hay, and is with difficulty extirpated. It is perennial, and matures an abundance of seeds.

The seeding of the flowers must be prevented by cutting the plants when half grown by the scythe or hand sickle, and the roots must be raised and destroyed by spades and forks.

22. The "Wood or meadow anemone," the "Anemone nemorosa" of botany, is a plant very common in meadows, though disregarded by farmers. The plant belongs to the 
class and order "Polyandria polygynia" of Linneus, and the natural order "Ranunculaceæ" of Jussieu.

Generic character.-Calyx none. Corolla : petals in two or three rows, three in a row, somewhat oblong. Stamina: filaments numerous, capillary half the length of the corolla; antheræ, twin, erect. Pistil : germs numerous, in a head; styles acuminate; stigmas obtuse. Pericarp none; receptacle globular or oblong, hollowed, and dotted. Seeds very many, acuminate, retaining the style.

Essential character.-Calyx none; petals six or nine; seeds many.

The "wood anemone" has the seeds acute; leaflets gashed; stem one-flowered. The root is perennial, and the height of the whole plant is from five to ten inches. It grows in woods among bushes, and in hedges, and in pastures, and flowers in March, April, and May. In fine clear weather the blossoms are expanded, and become so erect as to face the sun; but in the evening, and in wet weather, they are closed, and hang down. The plant is acrid, and in some degree poisonous. Horses, cows, and swine refuse it.

The root, being perennial, must be raised and destroyed by spades and forks; but such plants generally yield to good top-dressings, and pasturing of the land with sheep, assisted by folding the animals in order to deposit the excrements regularly over the surface.

23. The "Water cowbane," or the "Cicuta" of botany, is a plant of a poisonous nature, and communicates an unpleasant odour to the milk of cows that eat the plants. The plant belongs to the class and order "Pentandria digynia" of Linneus, and the natural order "Umbelliferæ" of Jussieu.

Generic character.-Calyx : umbel universal, roundish; rays very many, equal; partial roundish, with very many equal setaceous rays; involucre universal none; partial manyleaved; leaflets bristly, short; perianth proper; scarcely visible. Corolla universal, uniform, floscules all fertile; proper of five, ovate, inflected, nearly equal petals. Stamina : filaments five, capillary longer than the corolla; antheræ simple. Pistil : germ inferior; styles two, filiform, longer 
than the"corolla, permanent; stigmas headed; perianth none; fruit subovate, furrowed, bipartite. Seeds two, subovate, convex, and striated on one side; flat on the other.

Essential character.-Fruit subovate, furrowed.

The most common species is the "Cicuta virosa," or longleaved water hemlock, which has the umbels opposite-leaved, petioles margined, obtuse.' Stem round, hollow, two, three, and even four feet high, striated, smooth, reddish towards the bottom, dichotomous; leaves sheathing, a foot and a half long, and near a foot broad; the lower on long hollow petioles, the upper almost sessile, bipinnate; some of the pinnas simple, others bifid or trifid; the serratures sometimes brown; the end leaf cut into three to the bottom; all smooth.

This plant flowers in July and August, and is one of the rankest of our vegetable poisons. Some writers have known cows killed from eating it, and that horses and sheep eat it with safety. It ought to be very carefully removed from pastures by digging up and destroying the roots.

24. The "Meadow saffron," or the "Colchicum" of botany, is a very common weed in pasture and grass lands. The plant belongs to the class and order "Hexandria trigynia" of Linneus, and the natural order "Junci" of Jussieu.

Generic character.-Calyx a spathe. Corolla monopetalous, tubular, very long, springing immediately from the root; border campanulate, deeply divided into six lanceolate, egg-shaped segments. Stamina : filaments six, awl-shaped, shorter than the corolla, inserted into the tube; anthers oblong, four-valved, incumbent. Pistil : germen superior situated at the bottom of the tube of the corolla, contiguous to the root below the surface of the ground; styles three, a little longer than the stamens; stigmas reflexed, channelled. Pericarp: capsules three, inflated, coherent in their lower part, slightly separated towards the summit, opening longitudinally on the inner side. Seeds numerous, almost round, wrinkled.

Essential character.-Calyx a spathe. Corolla six-cleft; tube springing immediately from the root; capsules three, connected, inflated, with many seeds. 
The "common meadow saffron," or the "Colchicum autumnale," has the leaves flat, lanceolate, erect. Root bulbous, fleshy, milky, perishing after the ripening of the seeds; but first throwing out a lateral bulbous shoot, which produces the flowers of the ensuing year. Flowers generally purplish, opening in the latter end of September without stem or leaves. Leaves appearing in the ensuing spring, a foot long, broad, flattish, obtuse, dark green, upright, three or four together, sheathing. Capsules rising with the leaves, and ripening the seeds in May. The smell of the plant is very strong and nauseous, and the succulent bulb is poisonous to man and beast.

In an agricultural point of view, it is certainly a noxious weed to the farmer ; not, indeed, on account of its poisonous qualities, for neither cows, horses, nor sheep will touch it; but on account of its broad leaves, which occupy the place of better herbage. The only method of getting rid of it, is to dig up the bulbs with a spade, and to replace the earth when they have been separated from it.

25. "Treacle mustard," or the "Thlaspi" of botany, is not uncommon as a weed in meadows and pastures. It belongs to the class and order "Tetradynamia Siliculosa" of Linneus, and the natural order "Cruciferæ" of Jussieu.

Generic character.-Calyx: perianth inferior, of four, ovate, concave, somewhat spreading, deciduous leaves. Corolla cruciform, equal, of four obovate petals, twice the length of the calyx, with narrow claws. Stamina : filaments six, but half the length of the corolla, the two opposite ones still shorter; anthers pointed. Pistil: germen superior, roundish, compressed, emarginate; style simple, the length of the stamens; stigma obtuse. Pericarp: pouch compressed, inversely heart-shaped, emarginate, the style being mostly the length of the notch in which it stands, of two cells, the partition lanceolate; and the valves boat-like, with more or less of a dilated keel. Seeds : several in each cell, pendulous, inserted into the sutures, roundish, compressed.

Essential character. - Pouch compressed, emarginate, inversely heart-shaped; its valves, boat-like, keeled. Seeds several. 
The "common penny cress, or smooth mithridate mustard," or the "Thlaspi arvense," has the pouch orbicular, compressed, entire at the base. Leaves oblong, toothed, smooth. It is annual, and flowers in June and July. The root is small and tapering. The whole plant is smooth, about a foot high, branched; the stem leafy, angular upwards. Leaves two or three inches long, clasping the stem with their arrow-shaped base, their edges wavy and toothed. Flowers numerous, small, white. Pouch large, erect, almost perfectly orbicular. Seeds numerous. The warm pungent taste of the plant is combined with a disagreeable garlick flavour.

The root being annual, it only remains to guard against the perfecting of the seeds, by frequent cutting off the growing stems by the scythe.

26. The "Goose-tansy, silverweed, or feathered cinquefoil," or the "Potentilla" of botany, is a very common weed in pastures recently laid down from the arable state. The plant belongs to the class and order "Icosandria Polygynia" of Linneus, and the natural order "Rosaceæ" of Jussieu.

Generic characters.-Calyx : perianth one-leaved, flattish, ten-cleft; the alternate segments smaller, reflex. Corolla : petals five, roundish, spreading, inserted by their claws into the calyx. Stamina : filaments twenty, awl-shaped, shorter than the corolla, inserted into the calyx; anthers elongate, lunulate. Pistil: germens numerous, very small, collected into a head; styles filiform, the length of the stamens, inserted into the side of the germ; stigmas obtuse. Pericarp none. Common receptacle of the seeds roundish, juiceless, very small, permanent, covered with seeds, inclosed within the calyx. Seeds numerous, acuminate, wrinkled.

Essential character.-Calyx ten-cleft; petals five; seeds roundish, naked, fastened to a small juiceless receptacle.

The common species, or the "Potentilla anserina," has the leaves interruptedly pinnate, serrate, silky underneath; stem creeping; peduncles one-flowered. Root fibrous, and penetrating deep. Stems creeping, round, jointed, reddish. downy. Leaves, silvery, white underneath. Petals yellow, 
obtuse, twice the length of the calyx. Flowers from June to September.

This plant thrives best on damp poor clays, where water stagnates, and then dries up. It is held as a mark of the sterility of the soil. The roots are sweet like parsnips, and are used as bread. Cows, horses, and swine are said to eat it, and sheep to refuse it. The name would seem to imply that geese are fond of it.

In all arable lands, weeds must be eradicated by careful fall’wing; and on pastures, top-dressing the surface with composts, eating it bare with sheep, and the folding of the animals for the purpose of depositing the excrements, will in most cases remove the weeds of the smaller size.

27. "Rushes" of various kinds are often found on cold pasture lands. The generic and specific character of the plant, has been already given (page 42). The presence of the rush plant always indicates a superfluous moisture that wants to be removed, and, this object being effected by draining, the plant generally gives way to better herbage, though the extirpation and destruction afterwards will be much promoted and accelerated by top-dressings of ashes and other matters. The plant is not of difficult extirpation.

28. "Docks," "Rumex" of botany, are weeds mostly found on meadows and pastures of a strong and sourish nature, but sometimes of a very good quality. The generic and specific description has been already given (page 22). If the plants are permitted to ripen the seeds, they leave an immense quantity for future crops; and that being perennial the evil is very much increased. The plant is refused to be eaten by all sorts of domestic animals; and they should be rooted up after rain; and it is useful in some cases to cut through the stalks under the ground, and to repeat the practice as shoots are again thrown up.

29. "Bistort," or the "Polygonum Bistorta" of botany, is a very frequent weed on moist meadows. The description of the genus has been already given. It is perennial, and the root is a very strong vegetable astringent. The raising of the roots is the only effectual mode of eradication. 
30. "Restharrow," or the "Ononis" of botany, is sometimes found on dry, sandy pastures. The scientific description of the plant has already been given (see page 20). The young shoots are eaten by cattle, but the stems are too shrubby. The plant may be raised by the roots, but the least fibre that is left in the ground grows with fresh vigour. By constantly cutting the tender shoots with the hoe, the plants may be much weakened, and the final extirpation will be very much assisted by top-dressings.

31. "Thistles" are very common weeds on good dry, sound lands. The scientific description has been already given (p. 19). The plants are perennial, and grow very vigorously in some soils; the roots are very strong, and shoot laterally to a great distance. The growing plants must be cut when half-grown, in meadows by the scythe, and in pastures by a sharp hoe; and the roots may be drawn after soaking rains, when the plants are in full blossom, and before the seeds are ripened; the hollow root parts will be best rotted on the stems being cut over.

.32. "Ox-eye great white daisy," or the "Chrysanthemum Leueanthemum" of botany, is a very common weed on the best and soundest pastures. The scientific description of the genus has been already given. It is not grateful to any grazing animal: when the plants are few, the roots may be drawn; but where the weed is very abundant the surface must be heavily top-dressed, eaten bare by sheep, and improved by folding the animals over it.

33. "Crowsfoot plants," or the "Ranunculus" of botany, abound very much in various kinds, over the best meadows and pastures. The scientific description of the genus has already been given. The "bulbous-rooted, bitter, and creeping" species, are difficult of distinction, and grow very much intermixed. It is doubtful if grazing animals relish these plants to eat, as they cannot avoid them in the mixed herbage. The acrid pungent quality may be useful in stimulating the digestive organs; and when made into hay, the plants are said to lose the pungent quality; and the brightness of the blossom shows that the hay has been well got. 
The seeds produced are very numerous, and the roots are perennial. The only mode of eradication is by top-dressings, and by using sheep as before recommended.

34. "Mint," or the "Mentha " of botany, is a very common weed in moist pastures. The scientific description of the genus has already been given. At the end of the year, when pastures are bare, cows will eat it largely, and then it prevents the coagulation of the milk. The removal of the wetness of the land by draining, is the first step of eradication, and then to be finished by top-dressings, and by using sheep as before mentioned.

35. "Mouse-ear scorpion grass," or the "Myosotis scorpioides" of botany, is a very common weed on dry sheep walks. The generic description has already been given. It is said to be hurtful, and even fatal to sheep. Being low in growth, it must be eradicated by top-dressings, as before mentioned.

36. "Rag-wort," or the "Senecio Jacobea " of botany, is a very common weed on good lands. The scientific description has already been given. The herbage is constantly refused by cows and horses, and sheep will eat it only when young. It is a sure mark of good quality of the land. Mowing of the stems prevents the perfection of the seeds, but does not destroy the roots. This is best done by eating down the plants when young, with sheep, or pulling the roots after soaking rains; and they must be raised very carefully, as, the very smallest fibre being left, the roots will strike again.

37. "Mosses," or the "Musci" of botany, are the greatest pests of damp and heavy land meadows, and also on dry pastures. They belong to the cryptogamic class of vegetables, and form a very extensive order. Herb leafy. Corolla like a hood, bearing the style, and covering the capsule, which is closed with a lid. Roots fibrous and branched. They are not confined to the base of the plant, but are abundantly protruded, in five minutely jointed branched tufts from various parts of the stem, which, no doubt, imbibe nourishment as well as moisture. The stem is often simple, and frequently branched. Leaves invariably simple and undivided, the mar- 
gin only being serrated, and in some few instances being toothed. The fructification is sometimes lateral, and in that case always axillary, but sometimes terminal.

Various plans have been adopted and recommended for the extirpation of mosses. The most plausible is to scratch and tear the surface of the ground with sharp-teethed harrows, to apply a good top-dressing, and to sow the seeds of grasses. Another cure consists in folding sheep on the surface. But these modes are only temporary, for in a very few years the mosses again appear, and usurp the dominion of the surface. Experience has shown that breaking up the land, and relaying it with fresh seeds, is the only effectual cure, after the land has been well fallowed, cleaned, and manured, subsequently to the bearing of culmiferous and leguminous crops. This mode is the most effectual, and consequently the most economical in the end.

A notice and description might be added of some weeds that are very commonly found on road sides, and by the roots of hedges and fences. But such plants are very easily known, and should all be cut by midsummer, and the labour will be repaid by the value of the ashes when burned. The seeds of such weeds when perfected, are blown by the wind, and carried by birds, and consequently infest the meadows and arable fields. A compulsory clause should be inserted into every lease or agreement of holding land, that these weeds be all cut by midsummer, on every road-side and fence-root on the farm and the sides of the main roads; and the ditches must be cleaned by the notice of the commissioners. Seeds of weeds are perfected in such places in quantity sufficient to stock the whole neighbourhood; and a careful farmer is often put to very considerable expense in paying for his neighbours' neglect. It is a part of the land-agent's business, or of his deputy, to see the performance of such very necessary clauses on every estate.

Weeds should be very carefully eradicated from all commons and unimproved lands, for, if the tardy wisdom of the human intellect be not yet ready for the inclosing and cultivation of every inch of reclaimable land, much good may be 
effected by destroying weeds, and substituting a better herbage, by removing the wetness, and consolidating the surface. This step would rencler easier, and more susceptible, the last and fast-coming state of arable cultivation.

Weeds may be divided into two very easily remembered sections of "annual and perennial." The first division are propagated chiefly by yielding a profusion of easily ripened seeds; the second spread mostly by the roots, while some plants in both sections possess the two properties in a very considerable degree. The first division of plants require the care of eradication to be bestowed before the seeds are ripened, or rather before they are half-ripened, for the vitality is very precocious; and this precaution must be used in completely fallowing the lands, and by drilling the crops, in order to affording opportunities of hoeing and hand-weeding. And, when the plants are very abundant, the better way is to carry them off the land, after being cut by the hoe. The perennial weeds are larger than the annual, and are removed by the stems being pulled by hand, or cut by the scythe or sickle, and by the roots being raised by the spade or forks, and destroyed. These two modes will comprehend the general destruction of the weeds, according to the nature of the plants. 

PART II.

\section{Z O O L O GICAL.}

QUADRUPEDS.

BIRDS.

INSECTS.

WORMS. 



\section{PART II. ZOOLOGICAL.}

\section{Sect. I. Quadrupeds.}

IT may be observed of animals, as in the case of weeds, that it must not be supposed that they are useless productions, because an abundance of them proves injurious to the specific object of the farmer. Insects and worms afford, by the decomposition of their dead bodies, a very fertilizing ingredient in the composition of soils, and the absence or presence of decayed animal and vegetable matters characterizes the fertility or barrenness of the different earthy formations. Many of the quadrupeds afford a most agreeable and delicate food, and several of the winged creation have been long used in affording a nutritious sustenance to the human race. Some animals of both kinds are of no immediate application, yet they may answer some purpose that has escaped our observation.

It seems reasonable to destroy those that appear the least useful, and to encourage the propagation of the others that are known to be productive of some benefit. And this principle is doubly enforced by the knowledge that the useless ones destroy the useful, according to the invariable law of nature, that the stronger animals live by devouring the weaker. And it so happens, that the weaker ones are the most useful.

As the produce of the earth raised at the cost of the farmer, maintains all the "feræ naturæ," either directly or indirectly, it follows that he must have the management and profit that can arise from the value of the useful animals in the same way as the other animals of the farm, for which he pays the usufructuary value. By this arrangement, no farmer would 
reckon an animal useless from which he derived any value; and that designation would only be applied to those animals which destroy the others that are valuable to him. A very narrow compass would then contain the list of organized bodies which do any damage to the cultivator of the earth, and he would have his attention more confined to the destruction of the real enemies of his business.

1. The "Fox" is an animal of the dog kind. In natural history, it belongs to the series Vertebrata; class Mammalia; order Sarcophaga, or preying; family Digitigrada, or toetreaders; genus Canis; and sub-genus Canis vulpes, or the common fox. The genus Canis contains the dogs, wolves, foxes, the civets and ichneumons; besides a few minor genera of recent introduction.

Incisors $\frac{6}{6}$; canines $\frac{1-1}{1-1}$; molars $\frac{6-6}{7-7}=42$ teeth. The incisive teeth are all placed on the same line, and are usually trilobate, before being worn by use. The upper molars consist of three small single-lobed false molars, one bicuspidate carnivorous cheek-tooth, and two small tuberculous teeth with flattened crowns. The inferior molars consist of four false molars, one carnivorous cheek-tooth, and two tuberculous grinders. The tongue is smooth. The anterior extremities are furnished with five toes, the posterior with four.

The fox inhabits all Europe, the cold and temperate parts of Asia, and Barbary also, but not the hotter parts of Africa. He abounds in North America, and is found in South America, as far as Chili, and occurs in all northern and temperate climates, differing in size and colour, according to the circumstances of the locality. In Europe it is chiefly distinguished by its long straight tail, with a white tip to it, and differs from the common dog in the length, dense disposition, and softness of the hairs, especially of those about its tail, which is bushy, much admired by the animal itself, and in cold weather wrapped round its nose; and in its smell, which is peculiarly rank and disagreeable. The smell of its urine is remarkably foetid, insomuch that the animal covers it in the earth. It 
makes use of the badger's hole, and uses its urine to expel the badger by the smell. Its usual colour is a reddish tawny, though sometimes white, and even black. The fore-feet and the tops of the ears are black; the ears are erect, and the lips are white. It digs a hole for itself in the earth, and is with difficulty tamed to lose its fierceness. The eye is most significant of fear and hatred.

In all countries the fox maintains the same cunning disposition, the same eagerness after prey, and commits the same ravages among game, birds, poultry, and the smaller quadrupeds. It is a beast of chase, usually very prejudicial to the husbandman, by taking away and destroying his lambs, geese and poultry. It will feed on flesh of any kind, and when urged by hunger it will eat carrots and insects, and the dung of other animals ; and near the sea coasts, from want of other food, it will eat crabs, shrimps, or shellfish. In France and Italy it eats the grapes, and gets very fat upon them, and the flesh is then reckoned to be good food. The fox is a great destroyer of rats and other field animals. It secures its prey by digging holes in several places, and there leaves it until the calls of hunger induce him to find it for use. It generally goes to a distance from its own haunts to commit plunder and thefts.

The fox is exceedingly voracious, and indisputably the most sagacious and most crafty of all beasts of prey. $\mathrm{He}$ eats flesh of all kinds, eggs, milk, cheese, and fruits. Young hares and partridges are very favourite food, and rats, fieldmice, toads, serpents, and lizards. He is also fond of honey, and destroys the hives of wild bees, wasps, and hornets. His artful cunning has ever been proverbial : when wasps fix on his body, he retires, and rolls on the ground for the purpose of crushing them, and soon returns to destroy the hive. $\mathrm{He}$ fixes his abode in a wood near to some cottages, where he listens to the crowing of the cock, and the cries of the poultry. He scents them at a distance, and chooses his time-he conceals his road as well as his design-he slips forward with caution, and sometimes even trails his body along. He leaps the walls, or gets underneath, and ravages the court-yard, by 
carrying off one animal at a time, which he hides separately, and making several journeys till the approach of the morning, or some movements advertise him to suspend his operations. In the same way he stealthily catches woodcocks and thrushes. He hunts the young hares in the plains, seizes old ones in their seats, and never loses those that are wounded - digs out rabbits in their warrens-discovers the nests of partridges and quails-seizes the hen on the eggs, and destroys a vast quantity of game. The fox sleeps in a round form like a dog; but, when he only reposes, he extends his hind legs, and lies on his belly. In this posture, he watches the birds along the hedges, and meditates schemes for their surprise.

The fox flies when he hears the explosion of a gun, or smells gunpowder. He basks in the sun, and very much enjoys the free air; but always chooses some covered place to be secure from surprise. His flesh is not so bad as that of the wolf: dogs, and even men, eat it in France, and in many other countries.

Foxes produce but once a year, and the litter is generally of four or five, seldom six, and never less than three. When the female is full, she retires, and seldom goes out of her hole, where she prepares a bed for her young. When disturbed, she removes her young to another hole, one by one. A fox in the first year is called a "cub;" in the second, a fox ; and afterwards an old fox.

The genus "Canis" is a very numerous family of animals, and it has been remarked that no one tribe has a more deadly animosity to each other. It is a fixed law of nature, that the stronger animals live by devouring the weaker; and even when the cravings of nature are not pressing the constitutional pugnacious disposition prompts most animals even of the same genus and species to fight and kill each other. Very many animals leave a scent or odour on their track, which is supposed to proceed from the perspiration of their bodies; but no satisfactory reason has been given of this peculiarity. Dogs are provided by nature with a number of very acute olfactory nerves in the nose, evidently given them for the purpose of following their prey, and which, joined to an un- 
tiring swiftness of foot, renders an escape from them almost impossible. The smell of the fox is proverbially offensive, and is supposed to proceed, as in many other quadrupeds from certain glands, situated near the tail ; yet Linneus supposed that it arose from the upper part of the tail, where an ambrosial odour has been found; and that a violaceous scent proceeds from a spot on the tail. The smell of the fox in general so exactly resembles that of the root of the "crown imperial" as not to be distinguished.

The above qualities having been very early discovered, that certain animals emit an odour which other animals inhale, and which directs the pursuit of the former, the hunting of the one animal with a multitude of others became, and is yet continued as a manly sport, and a favourite exercise. But there can be no pleasure where pain is inflicted on any living thing; and the sight of the pangs of expiring life can afford no satisfaction to the eyes of sense and feeling. The fox is strictly a carnivorous animal, and is injurious to the farmer only in the case of destroying poultry: the destruction of hares and rabbits does not concern him, unless he be allowed a share in the use of them. A multitude of persons on horseback, galloping over a farm, leaving gates open, breaking fences, and treading on sown grounds, inflict an injury equal to the depredations of the fox; and the sport that may be afforded to the pursuers of the animal does not enter into the calculations of the farmer. When foxes become too numerous, they are best destroyed by baited gins, and a train made by drawing raw flesh across the usual paths or haunts to the gin, in order to allure him to the place of destruction. He may be also shot by watching times and opportunities. Hunting can only be considered as a relic of a barbarous age, when the uncultivated state of man " ranked him among the feræ naturæ."

2. The Polecat, or "Foumart," is the "Mustela" of zoology, a genus of the class Mammalia; order Sarcophaga, or preying; and family Digitigrada, or toe-treaders. The generic character is :- six upper fore-teeth, erect, acute, dis- 
tinct; and six lower, which are more obtuse and crowded; two are placed within; the tongue is smooth. The divisions of the genus, or weezels, have "feet cleft." The polecat species, or the "Mustela Foina," has the body blackish tawny, throat and breast white. The appearance is very elegant. The length of the body from nose to tail is about eighteen inches, and the tail is ten inches. It is a native of most parts of Europe, inhabiting woods and fields, and preys on birds and other small animals. The young are easily tamed, and rendered domestic. It breeds in the hollows of trees, and brings forth from three to five young at a time. The skin is used as fur.

The weasel tribe of animals are carnivorous, subtle, and bold, and take their prey by surprise, and no animals are better endowed by nature for an insidious attack. Were they as large and powerful as they are active, wily, and daring, they would be more formidable than the lion or the tiger, and infinitely more destructive, as they kill when opportunity offers, by wholesale, sucking the blood, and devouring only a portion of their victims, thereby effecting a large waste of life. Their form is long and slender, and such is their snakelike pliability, that they can twist themselves in the most extraordinary manner, and insinuate themselves into holes and crevices which one would think impossible for them to enter. The limbs are short, but powerful, and the toes are armed with sharp claws; hence they climb trees, or the sides of rough walls or buildings, with great agility. In their movements they appear to glide along; but they can bound and spring with considerable vigour, and know well how to fasten on their adversary.

In attacking their victims, they generally aim at the neck, below the ear, where they pierce the large veins with their teeth, or they fix upon the back of the head, and drive their canine teeth through the skull.

Their habits are nocturnal or crepuscular. The day is passed in their retreats, such as the hollows of decayed trees, burrows in the ground, holes in walls, and ruined masonry, and fissures in rocks. As evening shades prevail, they rouse 
from their repose, and begin to prowl. The eyes are sharp and piercing, the ears small, and the senses of sight, smell, and hearing are very acute. The sub-caudal glands secrete a fluid of very unpleasant odour. It makes a most vigorous resistance when attacked by a dog or man, and will defend itself to the last.

In the neighbourhood of a farm-yard, the polecat is more mischievous than the fox : whole broods of chickens are often destroyed in a single night, and the bodies left on the spot. Ten ducks and as many large turkeys have been known to be destroyed in a single night separately. It finds access to the poultry house by scraping a passage below the walls or the threshold of the door. Winter is the time of its haunting the farm-yard; in summer, it resorts to plantations, woods, and preserves of game, where it lives on leverets, young partridges and pheasants, and on eggs. It is easiest destroyed by means of baited traps and gins.

3. The "HARE" is a small quadruped, and belongs to the class Mammalia; order Rodentia and Saltigrada; and family Hemiclaviculata, or provided with imperfect collar bones. The animals of this genus have two fore-teeth in each jaw ; in the upper jaw is a second inner row of foreteeth, considerably smaller than the outer or primaries; the fore-feet have each five, and the hind feet four, toes. These animals are very timid; they live on vegetable food; they use the hind feet in walking as far as the heel, running by a kind of leaps, or repeated bounds. They have either exceedingly short tails, named "scuts," or none at all.

The hare is the "Lepus" of the Romans, by whom the flesh was held in high esteem. The ancient Britons did not use it. The "Lepus timidus," or the common hare, has a very short tail, the ears longer than the head, and black at the ends. The eyes are very large and prominent; the chin is white, and the whiskers are very long; the hair and fur on its face, back, and sides, is white at the bottom, black in the middle, and tipt with tawny red; the throat and breast are red, and the belly white; the tail is black above, and white 
beneath ; and the feet are covered with hair even at the bottom. The animal inhabits all parts of Europe; most parts of Asia, Japan, Ceylon, Egypt, and Barbary. It is a very watchful, timid animal, always lean, and runs swifter up hill than on even ground; and hence, when started, it endeavours to run up hill. It frequently saves itself and escapes by various artful doublings. It lies in its seat all day, and feeds by night, and returns to its seat or nest among bushes or long grass by the same road it left it; it does not pair. The urine is fetid. The rutting season is in February and March, when the male pursues the female by the sagacity of its nose ; they breed often in the year-go with young thirty or thirty-one days, and bring forth three or four at a time ; they admit the male during the time of their gestation, and, as they are very lascivious, they have frequent superfetations. The male and female are very liable to be mistaken for one another. The mother suckles her young about twenty days. The fur is of great use in the manufacture of hats. They are very subject to fleas. The animal is about two feet in length, and weights eight to nine pounds, rarely twelve. Hares have neither eyelids nor eye-lashes, but a nictating membrane, which remains open while the animal sleeps; their sight appears to be imperfect, but they have an acute sense of hearing, and enormous ears in proportion to the size of their bodies. They move these long ears with great facility, and employ them as a rudder to direct their course, which is so rapid that they outstrip all other animals. The period of their natural life is said to be about seven years, and the males live longer than the females; they pass their days in solitude and silence, frequently in fear and trembling, as a falling leaf is sufficient to alarm them; their voice is never heard but when they are wounded or seized, and then it is a sharp, loud cry, somewhat resembling the human voice. They are easily tamed, but never become thoroughly domesticated, always regaining their liberty when opportunity offers. They have been trained to beat a drum, and to perform gestures in cadence. They possess sufficient instinct for their own preservation, and show much sagacity in escaping from their enemies : in this re- 
spect, they differ very much. They turn more or less white with age. They are thought to be longer and stronger in proportion to the coldness of the climate. They are much exposed to destruction by men, dogs, cats, foxes, wolves, and birds of prey-as owls, buzzards, vultures, and eagles; so that it is almost a miracle that any of them escape destruction.

The hare is a most timid creature, continually listening after every noise, and will run a long way on the least suspicion of danger; so that she always eats in terror, and runs herself out of flesh continually. They are made fat by feeding in a safe place, and without apprehension, which is done by stopping their ears with wax, and rendering them deaf, so that they do not get alarmed.

Hares feed on vegetables, and are fond of the bark of young trees, except that of the alder and the lime, which they never touch ; they are very fond of birch, parsley; and pinks. In hard seasons, they do considerable damage to young nurseries and orchards by barking the young trees, which may be prevented by surrounding the nursery with a close fence, and in the orchard each single tree may be surrounded to the height of two feet by a circular wire fence. It is customary to smear the trees with tar, which must hurt the trees, and is not so effectual as the wire fence, as it lasts only one year.

Hares are hurtful to the farmer only when they become very numerous, which may be easily prevented by occasional shooting; which liberty being given to the farmer, will prevent any damage, and afford him amusement, and give rise to no dislike. The hunting of hares to death by coursing with harriers or grey-hounds is so contemptible as hardly to deserve notice.

The flesh of the hare is dry; and the habitual exercise of the animal exalts its salts, and renders it somewhat alkalescent; and this tendency is much increased if it is killed immediately after being heated by strong exercise. It is best used in making soups. 
4. The "RABвiт" is a furry animal that lives on plants, and burrows in the ground. It is the "Lepus cuniculus" of zoology, being a species of that genus. Tail short, nearly the colour of the body, ears black at the tip, hind legs shorter than the body. This species inhabits naturally the temperate and the warm parts of Europe, and even the hottest parts of Asia and Africa. It is not indigenous to Britain, but succeeds very well in it. It will not live in Sweden, and the northern counties, except in covered houses. They were imported from Spain into Italy. They are not natives of the western world, but they have multiplied amazingly in South America, since they were carried thither. They are exceedingly prolific; they breed seven times in a year, and produce eight young at a time. They occupy dry sandy soils, forming long winding burrows ; they confine themselves to these holes in the middle of the day, and wander in the evening, night and morning, in the search of food. The flesh is white, and much esteemed. They pair, and are very faithful to their mates, but never cross with hares. The most remarkable difference between hares and rabbits is, that the former live above ground, and the latter below ground. The rabbit acquires full size in six months, and lives about eight or nine years.

The colour of the wild rabbit is brownish grey; and the tame varieties are black, uniform white, with fiery red eyes; pied, or mottled, black and white, and silvery grey, or ash colour, with tawny feet. They grow to a large size, and are fed in confinement.

The rabbit is granivorous, and is much more destructive than the hare to young plants. The numbers are greater, and the habits are more fixed, and the residence is more permanent. Winter vetches are much destroyed by them, as there is not any other tender vegetation at that season of the year to divert their attention. Young barley is a favourite food with them. But rapid-growing cereal plants soon push beyond their reach, and on thick crops on well-farmed lands the damage is little apparent. But on thin, straggling crops, the whole vegetation is often consumed near to the burrows, where the open crops admit their hearing and watching the 
approach of danger. The barking of young trees by rabbits, is prevented as for hares. The chief damage done by them, is by burrowing in the banks of hedge roots, where they undermine the growth of the plants, and prevent the consolidation. The furry down that is rubbed from their bodies, and which adheres to the quicksets in the very frequent passage to and from the field for food, is pernicious to vegetable life. But these results only happen from an over-abundant number of rabbits; when kept in moderate numbers, very little or no damage is observable. The destruction of them may be effected by shooting, or better by spreading nets over the mouths of the burrows, and sending muzzled ferrets into the holes, in order to drive them out. A moderate number is pleasant to behold; and, to a contemplative mind, no part of nature's works can be more pleasing, in a summer's evening, than these splendid minatures of creation, feeding and watching; washing their long ears and their face, with the forepaws regularly in alternation, and wetting the paw with their tongue, to make it abstergent, raising their ear's to listen, and setting the body bolt upright to behold from a greater height, and to command a longer distance. When the use of migratory animals becomes the "interim" property of the pro tempore domicile, as it most justly is, the farmer will delight in a moderate number of the rabbit, as a useful ornament to his interim property.

"Warrens" have been formed of wild rabbits, where they are confined within a certain space of occupation, and bred for the purpose of a hired profit. The purpose is answered, where there is a not very distant available demand for the flesh and the fur. Waste lands of a dry sandy nature, to admit the formation of burrows, might be profitably used in this way. But it supposes some cultivation to raise green food for summer and winter, and these spaces must be closely fenced during the growth of the plants. A portion of the ground would be very useful by being sown permanently with clovers and grasses, parsley and legumes. This would form a constant grazing ground; and other crops could be raised in inclosed spaces, to suit the different seasons of the year. 
Nature has so furnished the world with animals and vegetables that are suited to the constitutional materials of its form, that no part of the exposed surface of the globe may remain idle, if the very visible specimens and dictates of observation and reflection were duly entertained, and the necessary and very simple practices performed.

The MoLE.-The proper name of the mole is "Mouldwarp," meaning to cast up earth. It is the "Talpa" of zoology, and belongs to the class Mammalia, order Scarcophaga or preying, and family Insectivora, or Insect-eaters; of which the characters are : the front teeth in the upper jaw are six and unequal; those in the lower jaw are eight; the canine teeth are one on each side, the upper ones being the largest; and the grinders are seven in the upper jaw, and six in the lower. The "Talpa Europea," or the common mole, has a short tail, and pentadactylous, or five-toed, feet. The body is thick and cylindric; the snout slender, but very strong and tendinous; the head not distinguished from the body by any appearance of neck; the legs so extremely short, as scarce to project perceptibly from the body; the fore feet situated obliquely outwards, excessively strong and broad, and furnished with very large and stout claws, so as to give the animal the power of working under the surface with the utmost ease and readiness; the hind feet are small in proportion to the fore feet, and are calculated for throwing back with ease the mould from behind the creature, during its subterraneous progress; the tail is short and small ; the skin is much thicker and tougher in proportion than in other quadrupeds, and the fur with which it is covered equally surpasses that of other animals in fineness and softness. The muscular strength of the mole is very great, and it is enabled to force itself into the ground with an extraordinary degree of celerity. The general length of the body is about six inches, exclusive of the tail, which measures one inch. The sense of hearing is very acute and delicate. The eyes are holes adapted merely for the purpose of apprizing it of danger. The mole feeds chiefly on worms and insects, and occasionally on the roots of vegetables; but it is more carnivorous than frugivorous. In par- 
ticular circumstances, it is very fierce and voracious. It requires damp mould for the purpose of living. The colour is sometimes white, spotted, and cream-coloured. It swims well.

The health of the mole is liable to be injured by the too free access of air, and it very frequently changes its subterranean habitations. It is commonly found in soft fertile soils, and never in miry, nor in gravelly grounds. When surprised by water, it springs in haste to the surface; and in winter, and during rains, it betakes itself to the upper grounds, which are less liable to be inundated. In the spring it descends to the meadows, where it finds a loosened soil, and roots to feed upon. In long droughts it flies to ditches, or to the shelter of hedges, and near to a stream. In the spring months of February, March, April, and May, the female produces four or five young ones at a birth, in an arched recess prepared for the purpose under ground, in a situation somewhat elevated, and under cover of a bush or hedge. Four or five mole-hills are generally to be observed very near to the upper side of this recess. The animal cannot live long without being at work. Being obliged to search under ground for its food, as insects and roots, it forms very long tunnels or subterraneous passages that are generally parallel to the surface of the earth, and vary in depth from four to six inches, according to the changes of the seasons. Being equally afraid of cold and heat, they make the passages the deepest in summer and in winter. They are very timid when they perceive themselves in danger; they often penetrate perpendicularly to the depth of one foot and a half, below the level of their ordinary residence. The mole works in all seasons, but more languidly in winter. The male is very much stronger than the female, and raises a greater number of larger hills. Young moles raise shallower passages than the old ones. Moles work most briskly at sunrise and sun-setting: in time of droughts, they throw up hills only at sun-setting. In winter, they work only during gleams of sunshine.

When a mole changes its place, it throws up three, four, G 2 
six, or even nine hills of earth, according to its age. Consequently all the hills formed by any one mole communicate with one another by subterraneous passages. The mole much dreads the access of external air; and, if the tunnel or passage be opened, the animal will immediately come to the aperture, and construct an arch of loose mould over the hole, which it repeats if the hole be again broken open. On these two facts, the art of mole-catching is founded.

The mole is injurious to the farmer by raising heaps of earth on meadows and pastures, which destroy the grass below and around them, and in making tunnels or vacancies among and below the roots of green crops. Mole-hills also very much obstruct the scythe in mowing. On pasture lands, the hills must be spread thinly about by means of a light hand-spade; and on arable lands, and on mowed grounds, the animals should be destroyed. This purpose is effected by placing traps in the tunnels or passages, of the size and shape of the ruts, and sufficient to admit the body of the mole. A bait is placed in the trap, and secured by a string, which reaches upwards to the point of a curved rod fixed in the ground by the other end. The animal, in eating the bait, gnaws the cord, and, the bended rod being released, springs upwards, and carries with it the trap and the mole in it, suspended and strangled by the waist, by means of another cord which is fastened to the bended rod. The best time of the year for destroying moles is in the spring, when they move to the fields from the winter abodes on the sides of ditches, and from hedge banks.

Several practical writers have disputed if the mole be injurious to cultivation, reckoning the animal to be the destroyer of noxious insects, and to form a fine top-dressing, in the earth of the hills being spread over the pasture ground. But the wire-worm works so very rapidly, that no common number of slow-moving moles could arrest its progress; and the other hurtful insects are very much beyond the reach of the moles. On mowed grounds of all kinds the hills are very ruinous to the scythe; and they are often formed after the tall grass prevents their being seen 
and demolished. On turnip lands, when the plants are in the younger state, the runs of the mole often undermine and destroy the growth of a very considerable number of plants ; and potatoes are also hurt at that time. On pastures, the effects are not so evident, only the hills must be constantly spread abroad, or a quantity of grass is lost, and the objects are unsightly. Though the mole be not a foremost animal in point of destruction, yet we think it is sufficiently so to warrant its removal, or being kept in very moderate numbers.

The RAT is the "Mus" of zoology; and belongs to the class Mammalia; order Rodentia; and the family Claviculata; or, provided with perfect collar bones. The genus "Mus" contains a number of varieties; the generic character is: fore-teeth upper wedged; grinders three, rarely two, on each side the jaw; clavicles perfect. The whole genus is characterized as living in holes, or any concealed chinks, climbing and running swiftly; some of them swim. The naine is very frequently pronounced "ratten" or "ratton." The genus "Mus" is divided into five families: 1. Tail compressed at the end; 2. Tail round, naked; 3. Tail round, hairy; 4. Cheeks pouched; 5. Subterraneous or ground rats. The rat is the "Mus rattus," or black rat, of the second family, tail round, naked. It has the tail very long, scaly; body black, cinereous beneath. This species, though now common in most parts of Europe, is supposed to have been originally introduced from India and Persia. The word "rattus," or "rat" is modern; the Romans comprehended all kinds under the word "mus." None are found in Siberia or Kamtschatka. They swarm in Otaheite, and in the other Society Islands; and are met with in New Zealand and New Holland. In Otaheite they boldly attack persons when asleep. It was found native in North America, but was imported into South America in 1554.

The general length of the rat species; from nose to tail, is about seven inches; and of the tail, eight inches. The colour of the head, and of the whole part of the body, is a 
dark iron, or blackish grey; the belly is of a dull ash colour; the legs are dusky, and very slightly covered with hair; the fore feet have only four toes, with a small claw in place of a fifth; the tail is nearly naked, coated with a scaly skin, and marked with numerous divisions or rings. This animal breeds frequently, and commonly brings about six or seven young at a time. Sometimes they increase so very fast as to overstock the place of their abode, when they fight and devour each other. The female carries the young only for one month, and nurses one litter till she brings forth another.

6. The Mouse is the "Mus musculus" of zoology, and a species of the genus in the second family; tail round, naked. The colour is brown, ash-coloured beneath, with tetradactylous fore feet, pentadactylous hind feet, and a long nearly naked tail. It is a general inhabitant of almost every part of the old continent; and is supposed to have been imported into America, and it is now very numerous there, and in the adjoining islands. The mouse inhabits houses and granaries, follows mankind, eats all kinds of sweet and good provisions, and drinks little; is gentle and very prolific. It is devoured by rats, cats, weasels, owls, and hedgehogs ; is destroyed by elder and hellebore, and is said to possess some small electrical properties when alive.

Field Mouse.-The field mouse is the "Mus sylvaticus" of zoology, of the class and family with rats and the common mouse. The tail is long, scaly; body yellowish brown, white beneath; breast yellow. This animal chiefly frequents dry and elevated grounds, and is found in woods and fields in great plenty. It is very common in all the temperate parts of Europe. They retire into holes among brushwood, and under the trunks of trees, where they amass large quantities of grain, acorns, and nuts. Swine often find their nests, and devour both the animals, and the stores of food. They collect the new-sown grain, and also feed on the young plants. Their habitations are detected by small mounds of earth thrown up near the aperture, when, by following the passages, the whole burrow may be destroyed. 
The "Mus" genus forms a very numerous tribe of animals, which multiply very fast, and are very destructive. In our island, the common and field mice, and the rat, are the principal destroyers; but in other parts of the world, other species, still more formidable, are found. Some confine themselves wholly to vegetable food; while others are polyphagous, and destroy indiscriminately any animal or vegetable substance which they can get. Their pace is, in general, rather quick, and their residence is chiefly in obscure subterraneous retreats, from which they emerge chiefly by night. They are of a prolific nature, and the females are furnished with numerous teats. Some species are migratory; others are local, and attached to the same residence.

Rats and mice inhabit dwelling-houses, granaries, and corn ricks, where they commit very extensive depredations, devouring any cooked food, animal flesh, and grain. They make holes in walls, and below floors, and are destructive in various ways. Various methods have been recommended and used for the extirpation of these vermin. Poison is given in mixed lumps of some sweet and attractive le aven; but it is dangerous for other animals, as dogs and cats. Traps are used, but they require a troublesome attention. Cats are useful for killing them ; but cats in a granary distribute a most offensive excrement, which is a greater nuisance than rats and mice. But the most effectual mode is to keep some tame weasels, which can enter the holes of the rats and mice, and thus reach them in their abodes. The carnivorous voracity of the weasel is so very great, that it will not suffer a single animal to escape.

When new houses are erected, the foundations and corners should be carefully secured against the entrance of vermin, by mixing the mortar with gratings of iron and broken glass. The upper part of laid floors should be guarded with similar materials, in order to prevent the entrance of these burrowing animals, which destroy walls and floors as much as grains and cloths. Thatched roofs are very objectionable in lodging rats and mice. 


\section{SECT. II. Birds.}

The birds hurtful to the farmer are the "rook, the pigeon, the wood-pigeon, and the pheasant."

The word "fowl " is used to denote the larger, and " bird" the smaller kind of feathered animals. Among naturalists, birds are the second class of animals; a race of creatures sufficiently distinguished from the others in having the body covered with feathers, and two feet and two wings, formed for flight. Birds have the mandible protracted and naked, and are destitute of external ears, lips, teeth, scrotum, womb, urinary vessel or bladder, epiglottis, corpus callosum, or its fornix, (covering of the two lateral ventricles of the brain or its arch,) and diaphragm. Birds are parted into two large divisions: Land birds, and Water fowl. The first division comprehends six orders. 1. Rapacious; 2. Pies; 3. Gallinaceous; 4. Culombine; 5. Passerine ; 6. Struthious.

1. The Rook is a species of the genus Corvus, the crow or raven. It is the "Corvus frugilegus" of ornithology, of the order Picæ. Bill sharp-edged, convexed above; legs short, strong; feet formed for walking, perching, or climbing. The generic character: Bill sharp-edged, frontlet reversed. The rook is black; front subcinereous; tail roundish. It inhabits most parts of Europe, and extends as far as Western Siberia. It is a gregarious bird, and is sometimes seen in immense flocks, so numerous as almost to darken the air in their flights, which they regularly perform morning and evening, except in the breeding time, when the daily attendance of both male and female is requisite to the purposes of incubation, or feeding their young. They begin to build their nests in the month of March, at least in England ; and their society seems to be regulated by a complete system of jurisprudence. They seem to have some idea of separate property. No one is allowed to carry off the materials from another's nest, and every crime against the interests of the 
community is punished with severity. The delinquent is attacked by those who are invested with authority; he is by them chastised according to the nature of his offence, and sometimes banished from the commonwealth. They lay four or five eggs, and the male and female sit by turns. When the young are able to eat, they disgorge their food, which they keep in reserve in their craw, or rather in a sort of bag formed by the dilatation of the œsophagus. After the hatching season is over, they leave the lofty trees where they nestled, and return not again till the month of August, and begin to repair their nests in October. Herons often take advantage of their absence, to lay and hatch in their nests. Rooks remain the whole year in England; but they are birds of passage in many countries. In France, they announce the winter; and in Silesia, they are the forerunners of the summer. There are no rooks in Italy. The young ones are good eating, and little inferior to the pigeon.

Rooks are very noisy and clamorous, especially when they have young. Ten or twelve nests are sometimes found on the same tree, and a great number of trees, thus furnished, form a "rookery." They seek out retirement and solitude, but prefer settling near human dwellings.

The appetite of the rook is confined to grain, worms and insects ; it never prowls after carrion, nor touches flesh; it has also the muscular ventricle and the broad intestines of the granivorous tribe. They commit serious ravages on newsown corn-fields, and on barley and oats when nearly ripe. The strong bill penetrates the ground, and finds the root kernel, by following the tender shoot, so soon as it appears above ground. Large flocks fly together in the early harvest, and destroy the nearly ripened oats. They are also hurtful to the potato crops, both at the time of planting and of forming in the ground, as they are able to dig and find the tubers, and then eat them. In order to prevent their depredations, the simplest and most effectual method is by scaring them away by a person appointed to watch ; and the damage may be very much lessened by preventing the breeding of a large number by destroying the rookeries, and killing the young. A few 
are very pleasant to behold; when numerous, the balance is turned.

It has been argued, that the rook is not so injurious to the farmer as is supposed, as it destroys insects that are hurtful to the young crops. But the insects which it devours are not injurious, except in some few places and circumstances; and they contribute to fertilize the land by the decay of their dead bodies. The rook flies to great distances, and the ravages are extensive, and not confined to particular tracts of country. They are an impudent and mischievous race of birds, and should be allowed to multiply very sparingly. To winter-sown wheats, and in the spring, they are wholly ruinous, if they be not very closely watched; other food is scarce at that time, and they congregate in vast numbers on the newly stirred land, for the purpose of devouring insects and the grains. At that time, a large field will require more than one person to watch ; for the rooks, when driven from one place, will fly to another ; and, by dividing themselves into parties, they employ as many persons as the divisions they form.

2. The Pigeon is a fowl bred in small houses or cotes. It belongs to the class Aves; order Passeres; and genus Columba. The characters of the order : Bill conic, pointed; legs formed for hopping; toes slender, divided; nest formed with wonderful art. They live chiefly in trees and hedges; are monogamous, vocal, and feed their young by thrusting the food down their throats.

Generic character.-Bill straight, simple, tapering, sinking: at the tip; nostrils oblong; tongue entire. Specific distinction: Bill sub-arched; nostrils covered with a tumid membrane. These birds are remarkable for the delicacy of their bill, and short legs; their toes are generally red, and divided to their origin. They inhabit only the temperate and hot regions; some are seen occasionally in Russia and in Sweden, but they always migrate southward as the winter approaches. None are seen in Siberia or Kamtschatka.

The domestic pigeon is a well-known animal. They require a lofty building, well covered, and fitted up with numerous 
cells. Yet they are not domestics, but rather voluntary captives, or transient guests, who continue to reside in the dwelling assigned them, only because they are pleased with a situation which affords them abundance of food and comfort. In the wild state, the pigeon has two broods in a year; and in the perfect domesticated state they lay often ten, and even twelve times in a year. They seldom or never lay more than two eggs at a time; they incubate from fourteen to seventeen days, and one of the young is a male, and the other a female.

Pigeons are very quick of hearing, and have a sharp sight. They are very nourishing food, somewhat binding, strengthening and provoking urine; as the animals grow old, the flesh becomes drier, more solid, and harder of digestion. Of all domestic animals they are confessedly the most decorous, pleasing, and vivacious. The wanton dalliances of the bird have made it to be feigned to be the symbol of love. The cock and the hen sit on the eggs by turns.

Regular pigeon -cotes seldom, in these days, belong to a farm; but most farmers keep a few pigeons in roost over an under building, and opening by the gable-end, or in wooden boxes hung on the wall of a southern exposure. They are most particularly fond of pease and tare seeds, and, if they be numerous, they will damage a newly sown field of these legumes, and also in the fields when the crops begin to ripen. They can open the pods with their bills, but they cannot dig the ground like the rook. Beyond a certain degree, pigeons must be held to be injurious to the cultivation of grain : within due bounds, they do little harm; but, increased beyond it, they prove pernicious vermin, both to the new-sown crops, and to the early part of harvest. Watching the fields is the only guard against their depredations. They are timorous, and easily scared.

3. The Wood PIgEon.-This animal is much known by the name of the "cushat." It is a species of the Columba, and is the largest in size, being fully seventeen inches in length. The specific name is the "Columba palumbus," or 
ringdove; the bill is yellow in colour, the nostrils are covered with a mealy red fleshy membrane; the irides are pale yellow; the head, back, and wing coverts are bluish ash colour; the upper part of the back inclines to brown; the lower part, rump, and fore part of the neck, are pale ash in colour; the rest of the neck and the breast are vinaceous; the belly, thighs, and vent are dirty white; the hind part and sides of the neck are green gold, in some lights changing to blue with a copper gloss ; and on each side of the neck is a white crescent: the greater quills are dusky -all of them, except the outermost, have the exterior edges white; the secondaries are greyish brown; at the base of the bastard wing is a dash of white : the tail is ash-coloured above, with the end blackish, but beneath the base and ends they are black, the middle hoary; the legs are covered with feathers almost to the toes, which are of a red colour, and the claws are black. This bird is found throughout Europe; the greater part of them are emigrants in respect of Britain, departing at the end of the year, and returning early in the spring. They inhabit the woods, and build on the tops of boughy trees.

The wood-pigeon picks the seed of peas and tares when sown in the spring, and also when ripening in harvest. In the dissolution of snows, when the bulbs of Swedish turnips are exposed to view, the animal, being pressed for food, attacks the turnips, and with its strong bill it digs into the bulbs, and makes a hole, which retains water, and soon induces putrefaction. When the pigeons are numerous, very considerable damage is done in this way to turnip crops. But the animal is very timid, and easily scared; and the number of them may be easily kept within bounds. The cooing of this bird in a deep-shaded wood and in a still evening imparts a pleasing melancholy feeling that almost overbalances the small damage it inflicts.

4. The Pheasant is the "Phasianus" of ornithology, or the bird of Phasis, so called from being found in a native state on the banks of the Phasis, a large river of Northern Asia Minor. It is a species of our domestic poultry, and the 
generic characters are : bill short and strong; cheeks smoothed with naked skin; legs of the male, for the most part, spurred. The common cock is the "Phasianus gallus," and the common pheasant is the "Phasianus Colchicus ;" rufous, head blue, checks red, papillous; bill pale horn colour, tail wedged. The bird is about nineteen inches long, and weighs from two to three pounds in weight. The Argonauts first found it in Colchis, and imported it into Greece, whence it has spread very widely. We have no certain account at what time it was introduced into Britain.

The pheasant is a very handsome bird; the figure is dignified, the deportment bold, and the plumage resplendent. Though they may be domesticated, yet they always retire to a dark solitude, and live as far as possible from human dwellings. They breed once a year, and lay about twenty eggs. The time of incubation is from twenty to twenty-five days.

The pheasant is kept as a bird of pleasure in game preserves, where artificial cover is formed, and food is laid in profusion, in the shape of barley and potatoes. It eats all sorts of grains and herbs, and seeds of every kind, and also small insects. When numerous, they make depredations on new-sown beans, peas, and tares; and in early harvest they attack grain of every kind. The size of the body tramples down more grain than it eats, and the strength of the bill enables it to dig the ground for seeds. The injuries done by pheasants are doubly offensive to the farmer, as he is prohibited by the game laws from using any means of lessening the number of the animals. The keeping of such nuisances within proper bounds forms the true protection to agriculture ; and not the raising the prices of food by artificial regulations, in order to starve the consumers by placing beyond their reach the very first elements of existence. 


\section{SeCr. III.-Insects.}

AN insect is an animal without bones, but covered with a hard skin; it has six or more feet, and breathes through spiracula or pores in the side of the body: yet insects are very different from, and must not be confounded with, vermes or worms. Quadrupeds, birds, and fishes, have all an internal skeleton of bones, to which the muscles are affixed; but the whole interior of insects is composed of soft flesh, and the muscles are attached to an external shell, which serves the double purpose of skin and bone, and which is completely exemplified in the crab and lobster.

Another distinguishing criterion of insects is the colour of the circulating fluid or blood, which is never red; and though a red drop of liquor be obtained from squeezing the animal, it does not appear to be the blood of the animal. The assistance of the microscope discovers a circulation, but it is not red.

The insects and worms hurtful to the farmer are:-

1. Caterpillars.

2. Turnip fly, Aphis.

3. Wireworm.

4. Snail, or slug.

Insects are either oviparous, or viviparous; or the species is perpetuated by their laying of eggs, or by bringing forth their young alive. The former is the general case, there being but few instances of the latter. Insects propagate by laying eggs, in the winged state, from which they rise in the form of caterpillars or worms; thence into the state of "Chrysalis ;" and lastly into a "fly" state. The fly deposits the eggs in places of safety and of abundance of food.

1. Caterpillar.-It is the general name of all winged insects, when in the worm state.

The caterpillars that do damage to cabbages, turnips, and gooseberry bushes, are deposited in the "ovum" state by the 
white butterfly and the "Phalæna," both insects belonging to the order Lepidoptera, having four wings covered with five imbricate scales resembling powder or meal. The butterfly, or "Papilio," has the antennæ or horns thicker towards the tip, and the "Phalæna" has them thicker towards the base. Caterpillars appear in March, and are most frequent on cabbages and gooseberry bushes, though they are found at times on the leaves of all fruit trees. They are most voracious, and very quickly destroy every vestige of the leaves, and consequently prevent the development of fruit, and the growth of the vegetable. Various methods are used for removing them : smoking the animals to death by an upward flame of glowing brimstone, mixtures of black soap, flour of sulphur, mushrooms, and rain water, have been sprinkled over the trees and bushes; and "nux vomica" has been added with good effect. These and similar applications have all had a temporary effect, but the animals mostly always return in greater numbers. In gardens, where the extent of space is limited, and under the control of manual application, the most effectual method of destruction will be to shake the animals from the leaves, and catch them in a basket, and remove them wholly beyond the garden. Those that fall to the ground can be gathered up by spade or besom. The cabbages may be freed of them in the same manner. In the field, where hand labour would be very slow on account of the extent of the ground, and where the space of the depredations is so much more extensive, rolling of the plants is the only effectual mode of checking the destruction. The roll may be light, and the operation may be more than once performed, as the animals, after being in any way removed from the leaves, will creep from the ground, and commence their work afresh. Applications of soot and hot lime have been used; but these substances only reach the upper part of the leaves, and the animals live on the under surface. Besides, it is not certain that these substances are destructive of animal life.

2. The Turnip Fly is the "Altica nemorum" of entomology, being a genus of "Chrysomela" of the Coleopterous 
order of insects, having two wing cases which shut together, and form a longitudinal suture down the back of the insect. The "Chrysomela" has the antennæ clavate, thicker towards the tip; the club solid or inflated; the body ovate, immarginate. The "Altica" belongs to the family Saltatoriæ of the Chrysomela genus, having the posterior thighs much thicker than the others, and incrassated and formed for leaping. The wing cases are yellow, with the margin entirely black.

This genus of insects are very numerous; and both in the larva and in the perfect state they are found in woods and gardens, and feed on the leaves of trees and plants, the tender parts of which they devour, and reject the fibres. Sometimes they infest the cotyledons only, and are very destructive. They are ruinous to the turnip plant when it has only put forth the first leaf: the number being in myriads, a whole field is often wholly consumed in less than one day of favourable sunshine. The leaf of the plant is either wholly devoured, or it is so very thickly perforated with holes, that the growth is ruined. A particular temperature is required to produce the fly, and consequently its attacks are not regular, but are directed by the seasons.

Various remedies have been used, and many more have been suggested in order to prevent the devastations of this insect. Sowings of soot and of quicklime, and decoctions of herbs, and sprinklings of urinary liquids, have been tried in vain. It has been suggested to squirt boiling water on the drills from a water-cart. But, if hot water did kill the animals, it might also injure the plants in that tender state. The most effectual preventive is to push the plant very quickly beyond the tender state, by means of the land being in very fine tilth, and the manure being already in an active state to stimulate the growth. When the second or the rough leaf of the plant is put forth, the growth is safe, as the fly never touches them.

3. The ApHis, or plant louse, is a genus of insects belonging to the order "Hemiptera" of zoology, having the upper 
wings half crustaceous, and half membranaceous, not divided by a longitudinal suture, but incumbent on each other. The generic character is :-Snout inflected; abdomen two-horned. The antennæ or feelers are longer than the thorax; the wings are four, and erect, or they are wanting; the feet are of the ambulatory kind; and the belly often ends in two horns, from which is ejected that most delicate juice called "honey-dew." The number of species is unknown.

These insects live entirely on vegetables. The loftiest tree is no less liable to their attacks than the most humble plant. They prefer the young shoots on account of their tenderness ; and on this principle often insinuate themselves into the very heart of the plant, and do irreparable mischief before they are discovered. But for the most part they beset the foliage, and are always found on the under side of the leaf, which they prefer, as it protects them from the weather, and other injuries to which they would otherwise be exposed. They also attack the roots and the bark. Some of the "aphides," as of caterpillars, are general, and others are particular feeders; and, like other insects, are more abundant in some years than in others. They are very common on hop plants, beans, peas, and sometimes on potatoes, and on most forest trees and shrubs. They appear in the spring with the first budding of the earliest plants, and proceed from small black oval eggs, which were deposited on last year's shoot; if they come too soon, the frost often destroys them all. Those that withstand the severity of winter, are full-grown in April, when they begin to breed, after twice casting off their exuviæ, or outer covering. Generation succeeds to generation during the summer, and the increase is very great. They have many enemies, or the number would become beyond endurance.

The "Aphis," by puncturing the tender leaves of plants, draws the juice to the wounded part, and exhausts it. The plant is thus deprived of the proper nourishment by circulation. Many plants grow deformed by the number of punctures made upon their leaves, and decay from want of the usual sap. Some thrive even when covered with these insects; while others rise up into small hollow tubercles, which, on 
being broken open, disclose the numberless families that inhabit them. The galls or excrescences formed by the plantlice, are often used in dying.

No preventive or cure has yet been devised for the ravages of the aphis; and the multitudinous attacks of the insect, and the smallness of its body, may ever render impossible the application of any remedy in the fields. In gardens, where the space is more limited, and the means more available, decoctions and liquids of noxious ingredients may be thrown upon the plants that are attacked, and somewhat check their progress.

4. The WeEvil is the "Curculio" of entomology, a genus of insects of the order "Coleoptera." The antennæ are clavated, and rest upon the snout, which is prominent and horny; feelers four, filiform; club solid or inflated. The species of this genus are very numerous, upwards of 600 are now known; many of them exceeding in brilliancy and lustre all powers of description, and principally distinguished by their colour.

The larvæ of this splendid tribe differ not from those of most other coleopterous insects. They bear a resemblance to oblong soft worms. They are provided anteriorly with six scaly legs, and their head is likewise scaly. But the places where those larvæ dwell, and their transformations, afford many singularities. One of the minutest species of "curculio," at first hardly discernible without the aid of a microscope, is the "Granarius," or "Weevil," by some called the "Bond." The larvæ are much dreaded in granaries, as they take up their abode within the grains of wheat. It is very difficult to discover them, as they lie concealed within the grain. There they grow at leisure, enlarging their dwelling-place at the expense of the meal, on which they feed. Corn lofts are often laid waste by these insects, whose numbers are frequently very great, and destroy much corn. When the insect is come to the full size, it remains within the grain, hidden under the empty husk, which subsists alone, and, there transformed, it becomes a " chrysalis ;" nor does it 
leave this abode till it becomes a perfect insect, and makes its way through the husk of the grain. It is not easy to discover the grains that are thus hollowed out, as they appear quite plump and full, but they are much lighter, and swim on the surface of water. Other larvæ of "curculiones" are not so fond of corn, but fix on several other seeds, as beans, peas, and lentils, and the heads of thistles and artichokes. The leaves of elms are often wholly destroyed by perforation.

The French call the corn insect "Calandre," and the word "calandra" has been admitted into English nomenclature. The animal pierces the grain with the trunk, and the female deposits an egg in the hole, which are hatched into small worms, which are usually found with their bodies rolled up in a spiral form; and after eating till they arrive at their full growth, they are changed into "chrysals ;" and from these, in about a fortnight, comes out the perfect "calandre," or beetle. The maggot is found in the centre of grains, without trace of an aperture. The insect probably lays the egg in the blossom. The bread made from the affected flour is unwholesome. The weevil is called "Calandra granaria."

The best remedies are perfect ventilation, and a constant shifting of the grain. But the most effectual remedy for the farmer, and total preventive, is to lay no corn in granary, but to sell and deliver it immediately on being threshed.

\section{Class IV.-WORMS.}

1. The Wireworm is a name given by farmers to the larvæ of several insects injurious to various crops; they are species of the genus "Elater," of the order "Coleoptera" of entomology. They get the name of "Elater" and "skippers or skipjacks," from a power of throwing themselves up in the air, when laid upon their backs. They have the antennæ filiform, and a pectoral spine springing from an abdominal pore.

Twenty-six species of the genus "Elater" are found in 
England. They are all easily distinguished from every other genus by the spine at the extremity of the thorax, a character which scarcely any other animal possesses. The larvæ live in decayed trunks of trees, and in hillocks of old-raised earths. The colour is yellow, with the head brown, and the extremities of the jaws black; the body constituted of twelve joints, shining, and hard-skinned; a few hairs appear over the body; under the first three joints are six horny and pointed feet; and at the beginning of the last joint, which is round, there are two black spots, one on each side, which are probably the apertures through which it breathes.

The wireworm is a most mischievous animal in different sorts of grain crops. It is very plentiful in old grass lands of inferior quality, and infests the crops for many years after the land is put under arable cultivation. They begin to work in March, and continue for about two months, during which time they heave and raise the soil by their under-ground movement, and cut the stems of the growing plants. The ravages are very often quite frightful on oats and wheat. Barley is later in being sown, and is not so much exposed to their attacks. They cease working after the stems become too strong to be gnawed and devoured. The animal is extremely tenacious of life, and not easily destroyed. Quicklime has been used; but experience has shown that the worm not only lives but thrives when laid among quicklime alone. Continued heavy rolling of the land serves to check their progress; but no thorough remedy has yet been found. The animal flies from wetness, and always retires to the top of the ridges where the land is dry. Where the land is flat, and where water stagnates, the animals may be drowned in winter, by laying the land in a level form over winter. Wetting and puddling of the earth most effectually banishes them. But few situations will admit this remedy owing to the natural formation.

2. The SNaIL is the "Limax" of helminthology; the slug or naked snail, a genus of the order "Mollusca," or gelatinous worms. 
Generic character.-Body oblong, creeping, with a fleshy kind of shield above, and a longitudinal flat disk beneath; aperture on the right side within the shield: feelers four, situated above the mouth, with an eye at the tip of each of the larger ones. Six species are known in Britain; they commit great depredations in fields and gardens, especially in wet weather.

The black slug has the body black, and furrowed with deep wrinkles. The length is from two to five inches: it crawls very slowly; the feelers are always black; back convex, shield rough, with numerous dots; abdomen wrinkled. It is common in woods, meadows, fields, and gardens.

The eyes of snails are in their horns, one at the end of each horn, which they can retract at pleasure. They produce young in the shape of eggs by the aperture of their neck. The copulation lasts ten or twelve hours, and they bring forth eggs at the end of eighteen days.

Snails destroy fruits and vegetables in gardens, from which lime and ashes, sprinkled on the ground where they most resort, will drive them away. Their ravages in fields are best prevented by rolling, as the bodies are tender, and easily killed or hurt by being squeezed. The rollings may be repeated. 



\section{WORKS ON AGRICULTURE, ETC.}

PUBLISHED BY

\section{ROBERT BALDWIN,}

PATERNOSTER ROW, LONDON.

\section{MODERN}

\section{AGR ICULTURAL IMPROVEMENTS.}

\section{BY CUTHBERT WILLIAM JOHNSON, F.R.S.}

In 8vo., with numerous Cuts, price only 3s.

BEING INTENDED, ALSO, AS

\section{A SUPPLEMENT TO THE BRITISH HUSBANDRY,}

Forming part of the Farmer's Series in the Library of Useful Knowledge.

** This little work is intended to include a detail of the chief modern practical improvements which have, during the last few years, or since the publication of "The British Husbandry," served so much to promote, to elevate, and to adorn the science of agriculture. A lengthened experience of the kindnesses which the noble farmers of his country have so liberally showered over his efforts in their service, assures its author, that this volume will receive at their hands full as much favour as it deserves. To these old and stanch friends it is dedicated; and, if it only serves in any degree to smooth the path of the young agriculturist, the essay will not have been written in vain.-Preface. 
THE

\section{LIBRARY OF USEFUL KNOWLEDGE}

Embraces, as one very conspicuous feature, a Library for the farmer, published under the denomination of the "Farmer's Series," and contains almost every thing requisite for the information of the cultivator of the soil, whether for profit or pleasure. It consists of Six Volumes, any of which may be had separately. The subjects are -

\section{BRITISH HUSBANDRY :}

Exhibiting the Farming Practice in various parts of the United Kingdom, with numerous Cuts of Farm Buildings, Agricultural Machines and Implements, \&c. In 'Two Vols. 8vo, of nearly 1400 pages (Mr. Johnson's Supplement being included), price 16s.

\section{A Volume entit'ed}

\section{BRITISH HUSBANDRY, VOL. III.}

Sold separately, and embracing the following Subjects, viz.:-

1. Reports of Select Farms in various parts of England, sold separate, ir boards, for $3 s .6 d$.

2. Outlines of Flemish Husbandry, by the Rev. W. L. Rham, separately bound, 1 s. $6 d$.

3. Usgeful and Ornamental Planting, by Mr. George Sinclair, separately bound, $2 s .6 d$.

4. The Cottager's Mandal of Husbandry, Architecture, Domestic Economy, and Gardening, by J. C. Loudon, F.L.S., \&c., separate, 1 s.

5. A Practioal Treatise on the Best Mode of Making and Repairing Roads, by Charles Penfold, Surveyor, a New Edition, enlarged, $1 s$.

Each of these subjects may be had separately. The whole in One Vol. cloth, 8s. 


\section{THE HORSE;}

Its History, Breeds, and Management.

By William Youatt.

With a Treatise on Draught, by I. K. Brunel, Esq. The whole Illustrated with numerous Cuts. In 8 vo., bound in cloth, $6 s .6 d$.

\section{CATTLE;}

Their Breeds, Management, and Diseases.

By William Youatt.

With beautiful Cuts of the various Breeds, Anatomical Illustrations, \&c. In 8vo., price, in cloth, 8s.

\section{SHEEP;}

Their Breeds, Management, and Diseases.

By William Youatt.

Illustrated like the Volume on Cattle; to which is appended the "Mountain Shepherd's Manual." In 8vo., price, in cloth, $8 s$.

\section{THE LIBRARY OF USEFUL KNOWLEDGE}

Comprises, exclusively of the Farmer's Series, Eighteen closely printed Octavo Volumes, besides some separate Tracts. A full Prospectus will be sent post-free, on application to the Publisher, Robert Baldwin, London.

$$
\text { By whom also are published, }
$$

\section{A DICTIONARY of MODERN GARDEN-} ING. By George William Johnson, Esq., Fellow of the Horticultural Society of India, and Corresponding Member of the Royal Caledonian and Maryland Horticultural Societies, and Editor of the Gardener's Almanack. In a small but closely printed Volume, price 10s. $6 d$.

** The following are among the numerous testimonials to the utility and value of this work.

The Gardener's Chronicle, May 23.-After speaking of the utility of the dictionary form for a work of this nature, which having heretofore required folios and 
quartos ,it might be thought impossible to compress into a duodecimo the endless details of modern horticulture, it says, "Nevertheless Mr. Johnson has made the attempt : his work consists of 700 pages and upwards, and contains about 3,500 subjects." After giving some extracts, it proceeds, "These specimens serve to show the general nature of Mr. Johnson's book. Its utility is indisputable, especially to amateurs and young gardeners. Its faults are those which are inseparable from its conciseness ; its merit is the skill with which the matter is condensed and selected."

The Gardener and Land Steward of March 30.- "We are glad to speak in terms of commendation of the manner in which the work is executed. Upwards of 700 pages are closely filled, and, in company with the letter-press, a considerable number of neat engravings are interspersed throughout. Treating, as it does, on the whole range of garden subjects, it is obvious that each must bear the impress of brevity; and so it does ; but one very meritorious feature of the work is the talent with which the necessary abridgment has been made."

The Atlas, June 6.- "Utility, more than either originality of contents or elegance of phraseology, has been the author's object; and he has attained it. The book is a compact mass of useful information, so arranged as to admit of instantaneous reference."

Douglas Jerrold's Weekly Newspaper, August 8.-_" A book of sound practical utility gains little by any eulogy; it will find its own way and rise into public estimation in defiance of all suicidal criticisms. We venture to pronounce the present a work that will conquer public favour. Not only is the subject a popular one, but the treatment of the vast variety of subjects it involves is condensed, clear, and judicious. We do not recollect so much and such various matter in any work of reference, and in so small a limit, as at once to save much of cost both in time and purchase-money. In treating of fruit-trees and of flowers, a sound practical judgment is displayed. The number of vegetative species is given in the aggregate in all cases; but as the work would be extended to a great compass, if every distinct species were named, those are recorded in full which are acknowledged to be the best." "We recommend this dictionary, therefore, to all our readers who are curious about, or attached to, what is at the same time the most primitive, pleasing, and healthy of pursuits, whether as a business or a pleasure. The whole is illustrated with neat wood-engravings explanatory of such objects as, being beyond the pale of verbal description, it is difficult otherwise to comprehend."

\section{THE PRINCIPLES of PRACTICAL GAR-} DENING. By the same Auther. Price $6 s$.

** The author's object in this work is to make the gardener acquainted with the principles on which his practice is founded. This has been his labour for the last twenty years; but he now gives the results of his researches and experiments in a collected and orderly form; thus aiming to advance plant cultivation from mere empiricism to the class of rational sciences.

\section{THE ART of BREWING. By David Booth.} Price $1 s$. in cloth, or in two numbers $8 d$. It is one of the Treatises in the Library of Useful Knowledge. 


\section{GUIDE to the CONSERVATORY; Being a} Concise Treatise on the Management of the Hothouse and Greenhouse; the Forcing of Bulbs, Shrubs, \&c.; and the best mode of keeping a Succession of Bloom through every month of the Year: exemplified in a Select List of the most admirable plants of the present day, under the arrangements both of Jussieu and Linnæusincluding their native country, propagation, and the soil adapted to each. By Richard Bainbridge, Flower Gardener to Lord Wenlock. In $12 \mathrm{mo}$, price $5 s$, , cloth lettered.

** The peculiar characteristic of this work is the means of obtaining a constant and large supply of flowers. It includes a very extensive List of Orchidaceæ, with their cultivation.

\section{A GRANDMOTHER'S ADVICE to YOUNG} MOTHERS, on the Physical Education of Children. By M. J., late Countess of Mountcashell. In $12 \mathrm{mo}$, price $6 s$. , cloth, a New Edition.

** "This book is the production of many years' experience, and much reflection; and the author trusts that it will be of use to those for whom it is designed-the anxious mother, the attentive governess, and the careful nurse."Preface.

\section{THE DISPENSING CHEMIST'S and} MEDICAL PUPIL'S ASSISTANT; containing Latin directions, with their translations, for every species of medical prescription; with several forms of ordinary prescriptions, and a succinct account of the properties and doses of the various medicines in common use, according to the new nomenclature of the Pharmacopœias of London, Edinburgh, and Dublin. By John F. Burke, Member of the Royal College of Surgeons. Inscribed to the Board of Examiners of Apothecaries' Hall. The Second Edition, price 2s. 6d., cloth.

\section{A GUIDE to the FRENCH LANGUAGE,} especially devised for persons who wish to study that Language without the assistance of a Teacher. By J. J. P. Is B.rethon. The Tenth Edition, revised and corrected by L. SANDIER, Professor of Languages, \&c., price, bound in cloth, 10s. $6 d$.

\section{A KEY to the EXERCISES in the above} work, by means of which any person of a mature understanding may acquire the elements of the French language practically, as surely as if a professed teacher were sitting by his side; and, with a very superficial knowledge of it, may teach it to others. Price $7 s$. 
9. A TREATISE on NAVIGATION and NAUTICAL ASTRONOMY, adapted to the Purposes of Elementary Instruction; with an Extensive Series of Examples for Exercise, and all the Tables requisite for Nautical Computations; with Rules and Examples adapted to the "Nautical Almanac" in its New and Improved Form. By Edward RiddLe, F.R.A.S., Master of the Nautical School, Greenwich Hospital. The Fourth Edition, in a large vol. $8 \mathrm{vo}$, price $10 s .6 d$. boards; or $12 s$. bound.

*** Dr. J. P. Dodd, of Trinity College, Dublin, in his "Lecture ou the Best Means of Promoting the Intellectual Improvement of Youth," says of "Riddle's Navigation"- "That admirable work contains both the Theory and Practice, being, in fact, a neat little course of Mathematics. It would be well for the naval and merchant services were it generally used in schools."

\section{TABLES of the LOGARITHMS of NUM-} BERS, and of Sines, Tangents, and Secants, to Six Places of Decimals. Extracted from Mr. Riddle's "Treatise on Navigation." Price $2 s .6 d$.

\section{A PRACTICAL SYSTEM of ALGEBRA,} designed for the Use of Schools and Private Tuition. By Peter Nicholson and J. Rowвотнам. Fifth Edition, price 5s. bound.

* * In this edition the authors have not only introduced some important original matter, particularly on proportion, imaginary quantities, binomial theorem, series, \&c., but have also endeavoured to illustrate many parts of the work by such alterations as will make it still more acceptable to the public.

12. A KEY to the above Work, containing the Solutions of more than 900 Problems, by the use of which, and the Algebra, a person may acquire a knowledge of this valuable science without the assistance of a Master. Price 8s. bound.

Just published, price $2 s$. $6 d$.,

THE PRINCIPLE and LAW of RATING, to the Relief of the Poor, Railway, Gas, Water, and other similar Companies; founded upon judgments recently delivered in the Court of Queen's Bench, and herein set forth; with observations thereon, and Forms and Tables for practically working out the same. By Charles Penfold, Surveyor, \&c., \&c. 





